\title{
HAFENCITY: MOBILIDADE, ACESSIBILIDADE E ESPAÇOS PÚBLICOS EM HAMBURGO, ALEMANHA
}

\author{
Arqt. ${ }^{a}$ Prof. ${ }^{a}$ Dr. ${ }^{a}$ Pérola Felipette Brocaneli
}

\begin{abstract}
RESUMO
A questão dos espaços públicos em áreas inundáveis é um assunto de preocupação internacional, mas que, na cidade de São Paulo, parece relegada a segundo plano, quando se observa que, no desenho da cidade, vias expressas e arteriais se desenvolvem em cotas de inundação. O projeto urbano HafenCity, em fase de implantação, apresenta um desenho interessante de espaços públicos e acessíveis, que considera as cotas de inundação, permitindo percursos em qualquer situação de cheia. Em maio de 2012, foi realizada viagem de estudo a HafenCity, para registro de alguns desses espaços públicos em fase de implantação. A visita in loco e o registro fotográfico desse projeto urbano revelaram detalhes interessantes da paisagem urbana de HafenCity, que se estendem além da preocupação com as cheias recorrentes, priorizando a mobilidade e a acessibilidade aos espaços públicos.
\end{abstract}

Palavras-chave: HafenCity, espaços públicos, áreas inundáveis, reestruturação urbana, acessibilidade e mobilidade.

\section{HAFENCITY: MOBILITY, ACCESSIBILITY AND PUBLIC SPACES IN HAMBURG, GERMANY.}

\begin{abstract}
The issue of public spaces on wetlands is a matter of international concern. In spite of this fact, this question seems to be relegated to the background in the city of São Paulo, once it is observed expressways and arterial roads developed on flooding levels inside the city. The HafenCity urban project, under implementation, presents an interesting design of public and accessible spaces, which considers flood quotas allowing paths in any situation of flood. In May 2012, held a study trip to HafenCity, aiming to record some of these public spaces being implemented. The visit to that site and photographic report of this urban project revealed interesting details of the urban landscape of
\end{abstract}


HafenCity, which extend beyond the concern with recurring floods, prioritizing mobility and accessibility to public spaces.

Key words: HafenCity, Public Spaces, Wetlands, Urban Restructuring, Accessibility and Mobility.

\section{INTRODUÇÃO}

Hamburgo é a segunda maior cidade da Alemanha, na foz do rio Elba, onde, dando acesso ao comércio fluvial e marítimo, está instalado o porto de Hamburgo, em meio ao segundo maior polo industrial do país.

O porto de Hamburgo completou 822 anos em 2012. Ocupa uma área de $75 \mathrm{~km}^{2}$, o que representa um décimo da superfície total de Hamburgo, em uma situação geográfica ideal, já que a cidade hanseática, coloca-se como ponto de trânsito entre a Escandinávia e os países do Leste da Europa. Esta localização torna o porto de Hamburgo extremamente interessante para as empresas de ultramar - da América à Ásia. Composto de 60 docas grandes e pequenas, diversos terminais para contêineres, pode receber simultaneamente mais de 300 navios para carga e descarga. Com capacidade para movimentar três milhões de contêineres ao ano, atualmente opera com $80 \%$ de sua capacidade.

Devido às características marítimo-fluviais, o porto de Hamburgo é procurado por navios cargueiros marítimos que sobem a foz do rio Elba, e também por barcaças fluviais provenientes do Alto Elba, que trazem cargas do interior da Alemanha e da República Tcheca, cortada pelo rio.

Em 2003, há quase uma década, a imprensa especializada ${ }^{1}$ já apontava esse porto como o segundo maior e mais importante da Europa, superado apenas pelo de Roterdã, na Holanda.

1 Porto de Hamburgo em expansão contínua. Disponível em http://www.dw.de/porto-de-hamburgo-emexpans\%C3\%A3o-cont\%C3\%ADnua/a-919605-1, visitado em 10/10/2012 
O porto de Hamburgo é o motor econômico e social de toda a região e tem condições econômicas, técnicas e estratégicas para expandir suas atividades, sendo um espaço de grande mobilidade.

Neste contexto, surge o projeto urbano HafenCity, a fim de reestruturar parte da cidade de Hamburgo diretamente ligada ao porto, e que se localiza em cotas inundáveis.

\section{HAFENCITY}

HafenCity é um antigo setor portuário de Hamburgo, objeto de projeto urbano, a fim de promover a transformação, reestruturação e revitalização dessa zona úmida, preservando as características do conjunto arquitetônico, constituído para dar suporte às enormes estruturas portuárias existentes no local. A zona úmida de HafenCity é bastante peculiar, pois apresenta até nove metros de altura de inundação, de forma que o desenvolvimento dos espaços públicos também equacionou com primazia a acessibilidade, nos diferentes níveis de atividade.

A modernização e reorganização dos espaços públicos, buscando uma melhor estruturação da área, incluem questões relacionadas à sustentabilidade urbana, preservando a memória portuária, inseparável da história local.

Richardsson (2005) afirma que o conceito de mobilidade permanece extremamente dependente do contexto a que se aplica, e cada país o desenvolve de forma diferente e em diferentes níveis, refletindo prioridades locais e regionais. Sistemas de transporte são complexos e respondem às diferentes demandas estruturais existentes, às diferentes organizações envolvidas, ao planejamento e à gestão local e regional. A complexidade da mobilidade se dá também devido aos sistemas regulatórios e de financiamento, tecnologias e modelos de uso do solo.

O projeto de HafenCity está em construção desde 2000, e a previsão de conclusão é para 2025, quando o projeto completo prevê moradia para 12.000 habitantes, e 40.000 postos de trabalho. Este projeto estimulará o crescimento do centro urbano de Hamburgo em até $40 \%$.

O objetivo do projeto elaborado para HafenCity é municiar, com uma rede de infraestrutura e espaços públicos acessíveis, esse setor da cidade que possui as qualidades 
de um centro urbano histórico, capaz de desenvolver as relações e funções de uma pequena metrópole, pois conta com parques, praças, passeios, serviços, museus, comércio, formando uma rede de espaços públicos capaz de identificar este antigo setor portuário de Hamburgo.

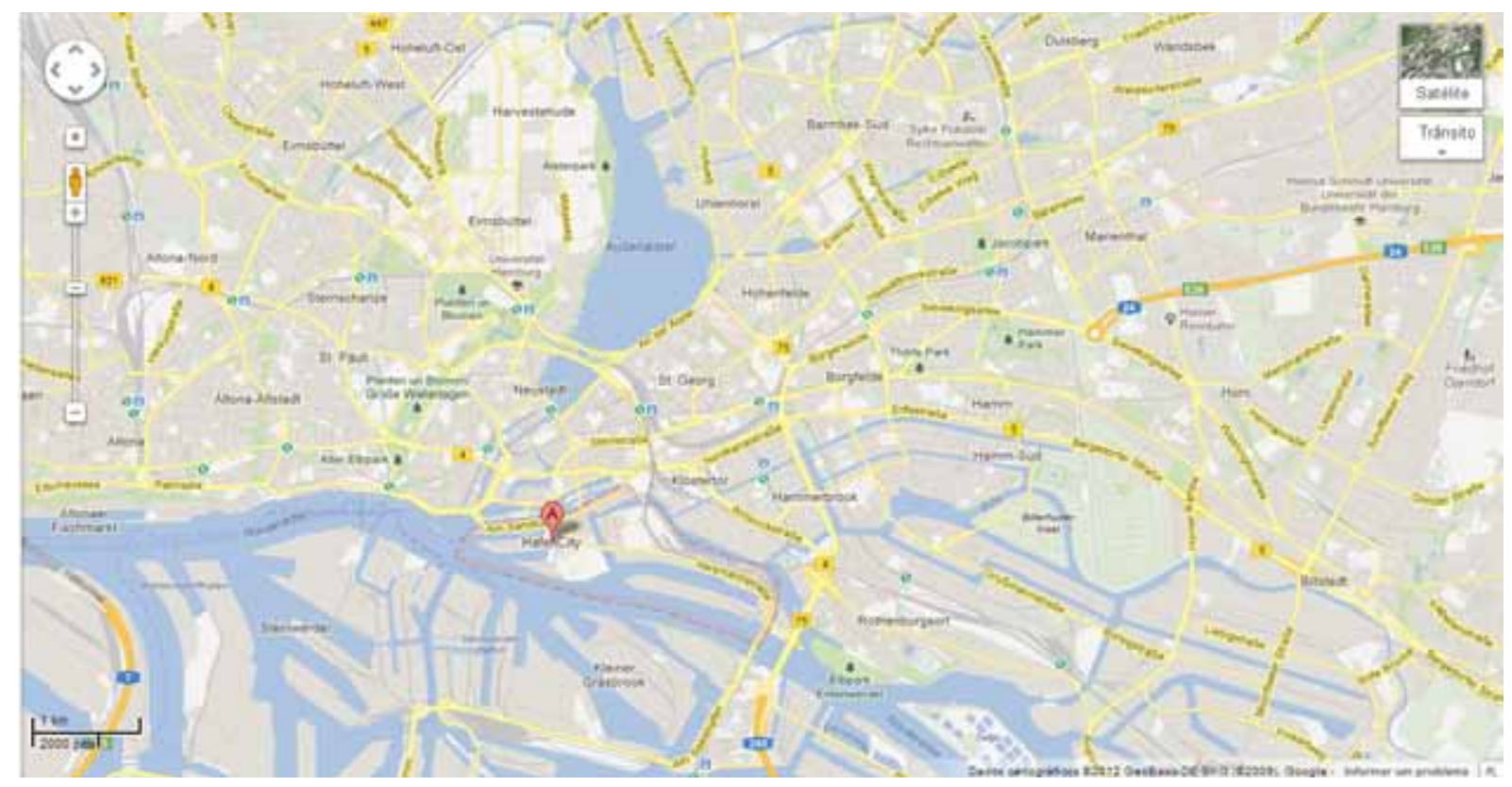

Figura 1: Localização de HafenCity (área A) em Hamburgo. Fonte disponível em https://maps.google. com.br/maps?hl=pt-BR\&tab=wl,visitado em 20/07/2012.

\section{Objetivos}

Apresentar alguns detalhes do projeto de espaços públicos desenvolvido em HafenCity, Hamburgo, que vai além do projeto de espaços públicos e cotas inundáveis, com base na leitura de paisagem efetuada durante visita de estudo ao local, em maio de 2012.

\section{Metodologia}

Para o desenvolvimento desta pesquisa, foi realizado levantamento e análise de bibliografia específica sobre o assunto, e uma visita ao projeto urbano de HafenCity, em Hamburgo, Alemanha, a fim de registrar os espaços públicos urbanos, desenvolvidos como instrumento de reestruturação urbana, em áreas de inundação recorrente. 
Foi considerado, como limite maior para a análise dos espaços públicos em HafenCity, o território delimitado para elaboração do projeto urbano. A visita fotográfica realizada in loco revelou detalhes da paisagem da cidade que extrapolam a preocupação com os níveis de inundação, sendo a questão da acessibilidade um aspecto importante, no projeto da paisagem da cidade.

\section{ESPAÇOS PÚBLICOS EM HAFENCITY}

O projeto urbano de HafenCity contradiz afirmações, como as de Pereira Leite (1997, p. 141), que expressam enfaticamente o desinteresse da população pelos espaços coletivos:

A renúncia ao espaço público da cidade fica caracterizada por uma série deprocedimentos diferentes: nas camadas mais altas de renda, pelo desenvolvimento privado de atividades culturais e de lazer; nas de baixo poder aquisitivo, pela impossibilidade de participar de atividades públicas ou culturais, seja pelo temor de sair de casa após o anoitecer - pois não há garantia de segurança - seja por sua marginalização do processo de desenvolvimento cultural; a atuação do poder público agrava essa situação, pelos procedimentos intimidatórios dos espaços públicos de uso coletivo, visando atender as alegações de caráter essencialmente discriminatório: falta de segurança gerada pela permanência, nas praças, parques e jardins, de desocupados ou suspeitos, falta de condições intelectuais para a participação em atividades culturais. A cidade responde a essa rejeição recíproca entre as classes sociais e o poder público, exibindo uma paisagem fragmentada e desorganizada: espaços privados fortemente defendidos e espaços públicos abandonados e deteriorados. (PEREIRA LEITE apud LOBODA, DE ANGELIS, 2005)

HafenCity apresenta-se como uma esperança para o desenho das cidades contemporâneas, pois o espaço urbano é alinhavado por espaços públicos, que por vezes são verdes, mas que, acima de tudo, estão interligando a cidade durante a época das cheias.

O projeto de HafenCity atende melhor às colocações sobre o espaço público de DaMatta (1997), que tem uma abordagem centrada nas diferenciações entre o privado e o público a partir de estudos antropológicos entre a casa e a rua, considerando a 
espacialidade física e moral, admitindo, no entanto, o estabelecimento de uma relação dinâmica e complementar entre os espaços públicos e privados, do que às colocações de Hertzberger (1999), que acredita em uma diferenciação gradual entre estes polos - público e privado, e foca sua discussão teórica em questões como acessibilidade, forma de uso e população usuária.

Os espaços públicos projetados em cotas de inundação apresentam material e acabamento resistentes aos períodos de cheia, como demonstram as figuras 2, 3 e 4 .
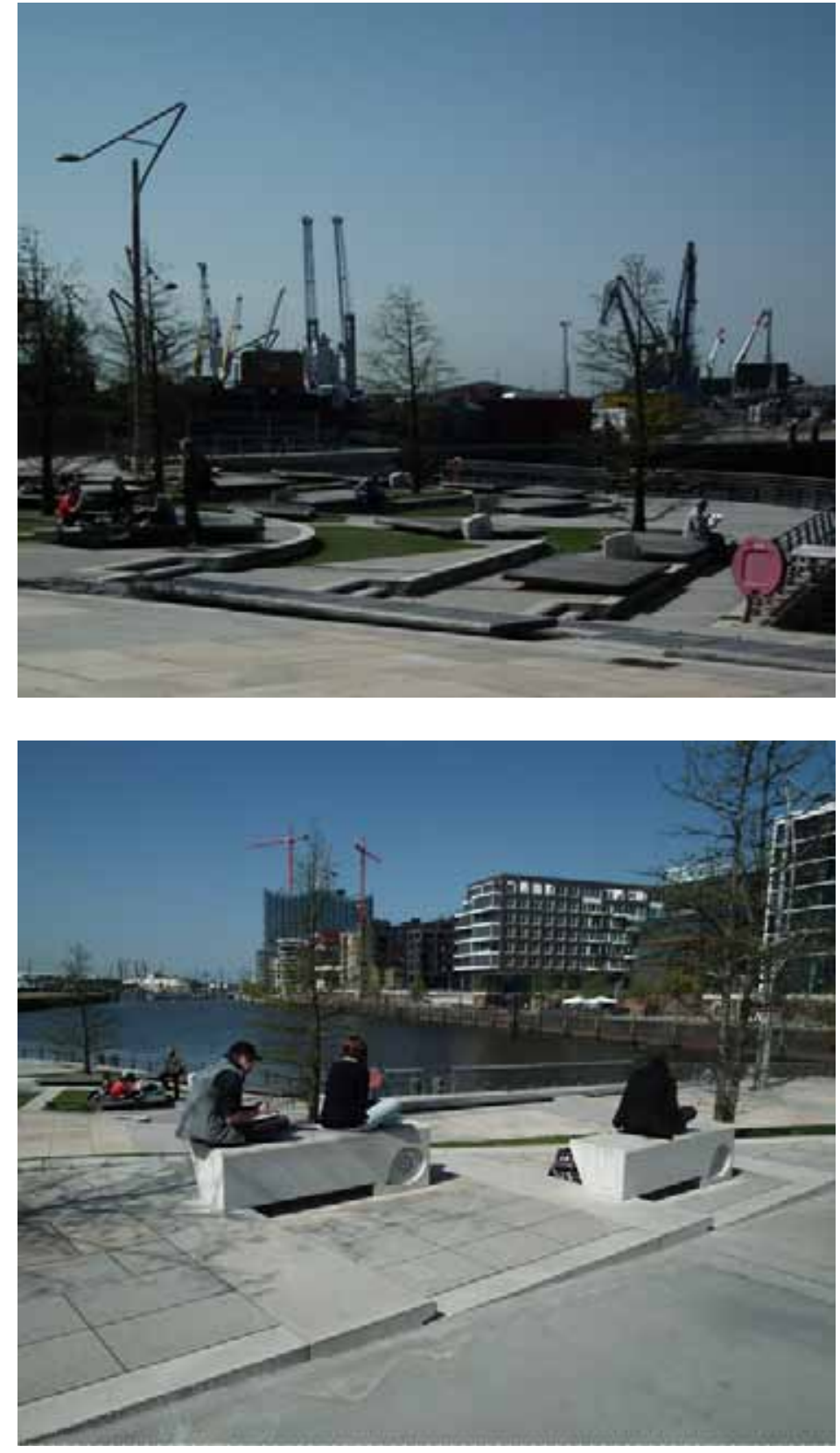

Figura 2: Diferentes áreas de estar, acompanhando as cotas de inundação, são projetadas de forma que o espaço possa ser aproveitado durante diferentes épocas de cheias. Foto da autora, maio/2012.

Figura 3: Os desníveis são acompanhados por bancos, que se apresentam também como equipamento de iluminação e identidade visual do projeto. Foto da autora, maio/2012. 


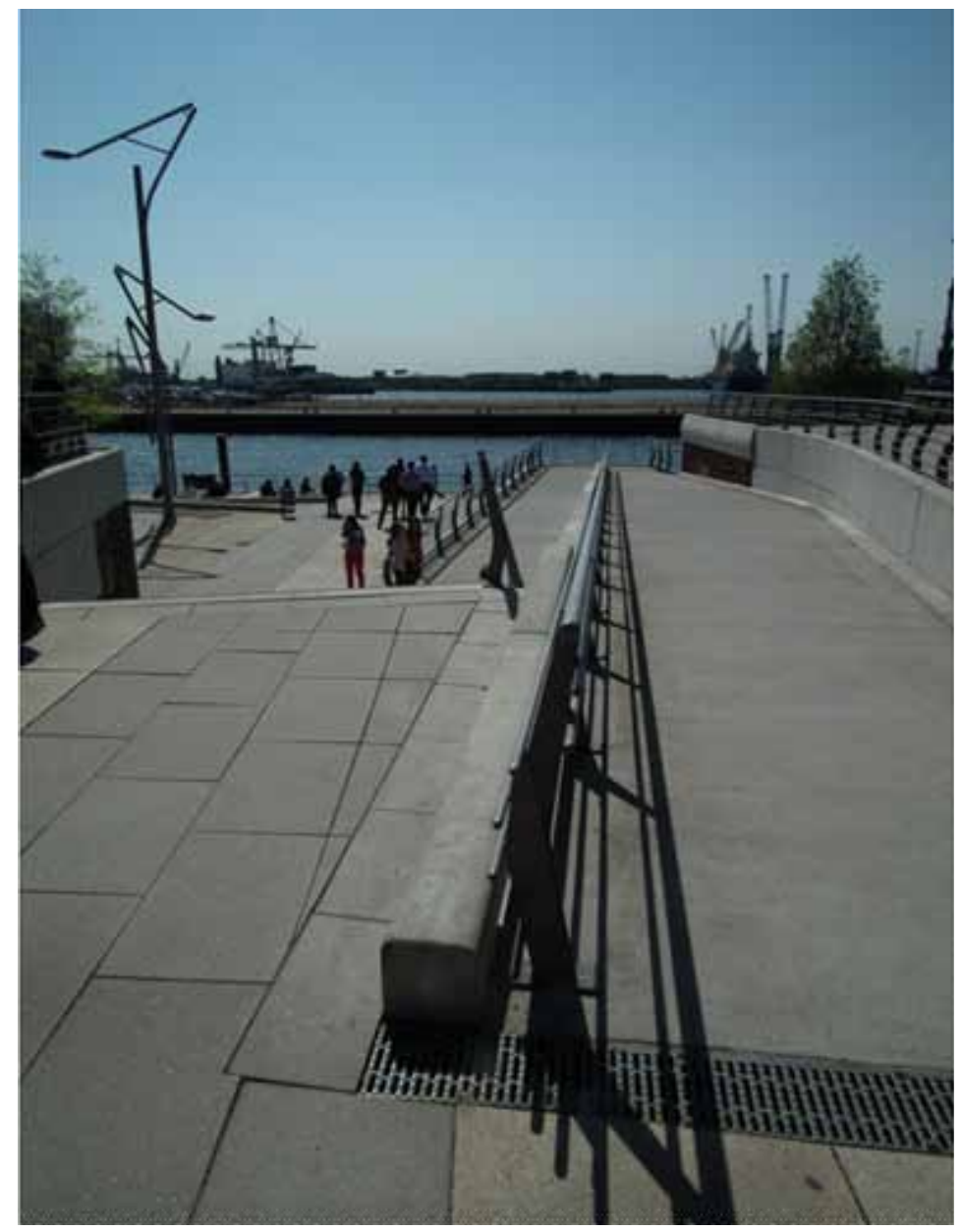

Figura 4: O desenho do espaço público desenvolve a acessibilidade e a mobilidade, distribuindo passeios agradáveis, em uma sequência de rampas e escadas que percorrem os nove metros de desnível, entre a cota de maior inundação e os percursos secos da área de HafenCity. Foto da autora, maio/2012.

A acessibilidade arquitetônica projetada para os diferentes níveis, conferem a mobilidade necessária ao uso e ocupação dos espaços públicos, fator fundamental para o sucesso da reestruturação urbana em HafenCity.

\section{ÁREAS VERDES PÚBLICAS EM HAFENCITY}

O desenvolvimento de espaços públicos associados a áreas verdes é uma questão projetual contemporânea, pois a estruturação dos espaços públicos nem sempre é verde, e muitas vezes não se estabelece de forma estruturada.

Dos significados de espaços urbanos e suburbanos encontrados, àqueles definidos por Di Fidio (1990) são bastante condizentes com o sistema de espaços públicos projetados em HafenCity, sendo que a definição de espaços verdes urbanos públicos é a que melhor descreve os espaços visitados. 
Espaços verdes urbanos públicos: praças; parques urbanos; verde balneário e esportivo; jardim botânico; jardim zoológico; mostra ou feira de jardins; cemitério; faixa de ligação entre áreas verdes; arborização urbana.

Figura 5: A sutileza do desenho de piso permite uma leitura clara do espaço, e a escala é adequada ao passeio público.

Foto da autora, maio/2012.

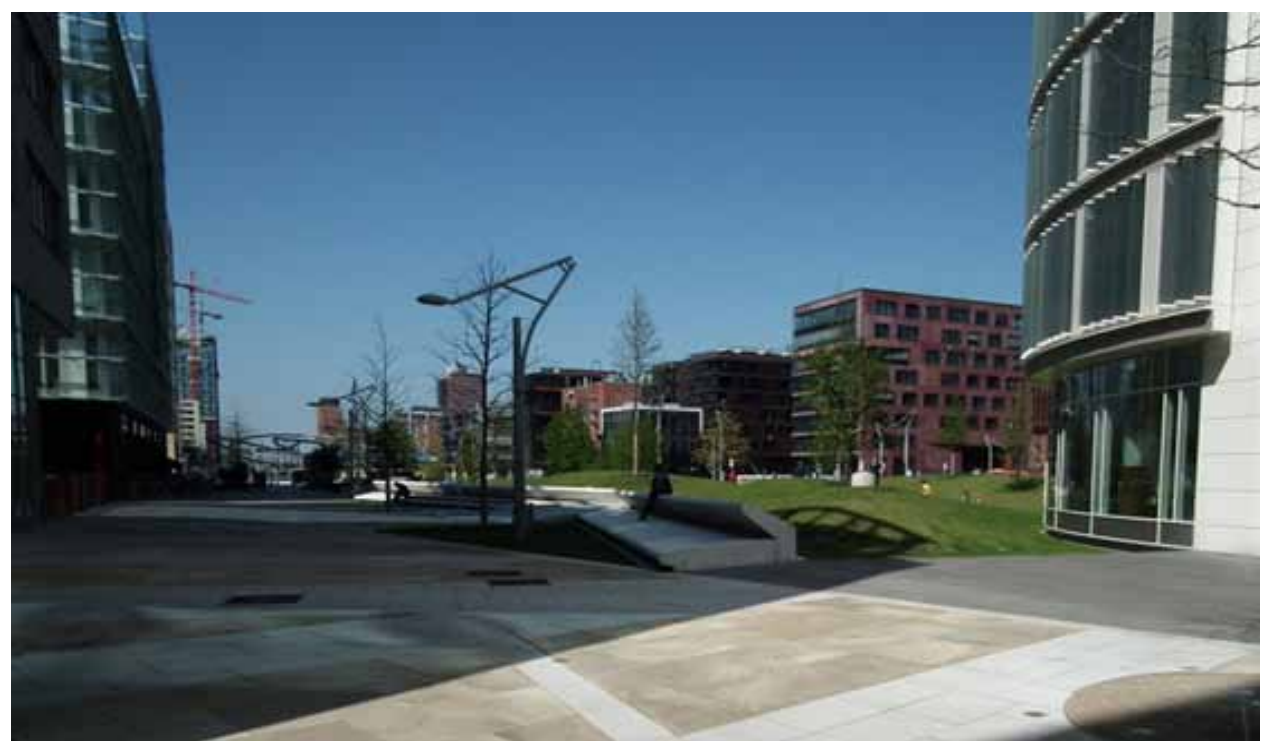

A abertura, como "uma leitura de paisagem", é descrita por Cullen (1981) como uma técnica de construção dos espaços públicos que se apresenta neste espaço, pois o percurso de pedestres se abre em uma praça pública, em meio a um conjunto de residências, comércio e serviços.

Nas figuras 6 e 7, o uso da estrutura dos bancos lineares, que percorre toda a praça, se apresenta como a "grande vedete" deste espaço público, pois abrange funções estruturais, de lazer ativo e passivo.

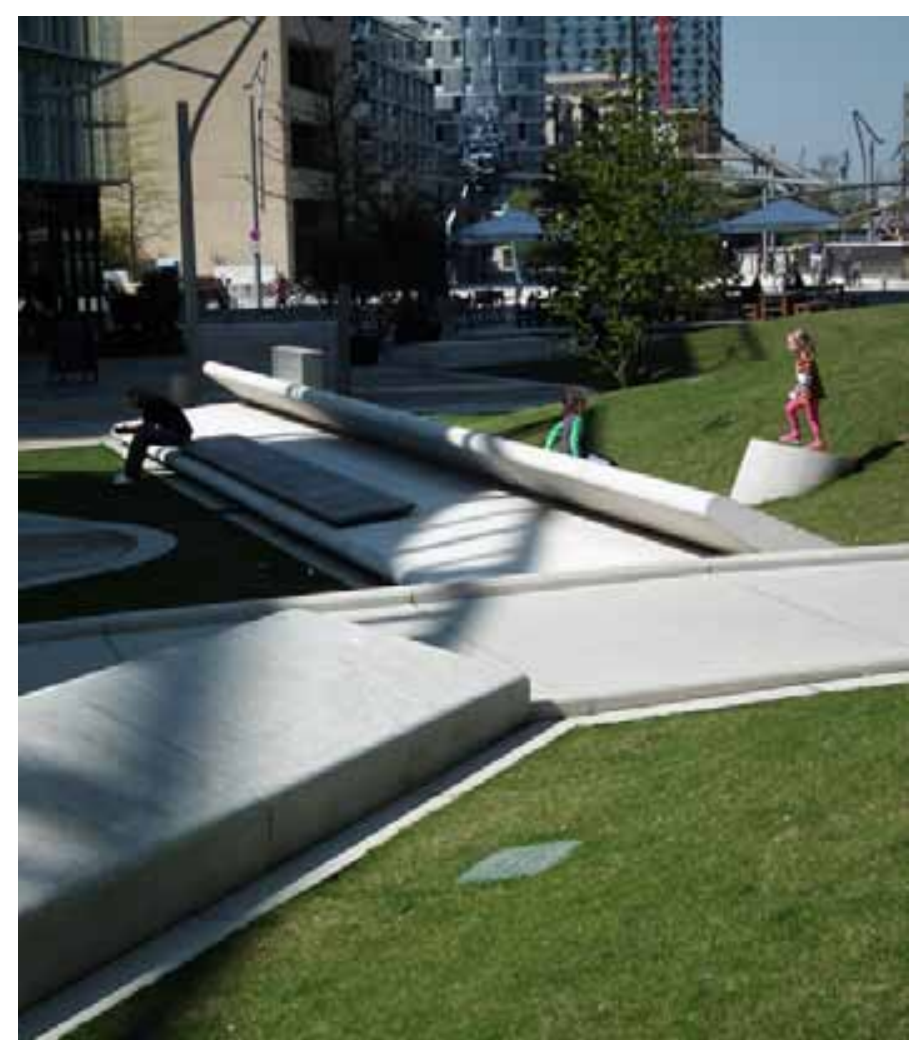

Figura 06: Este equipamento urbano pode ser utilizado de diversas formas e por diferentes faixas etárias, criando um espaço verde urbano público, democrático e interessante. Foto da autora, maio/2012. 

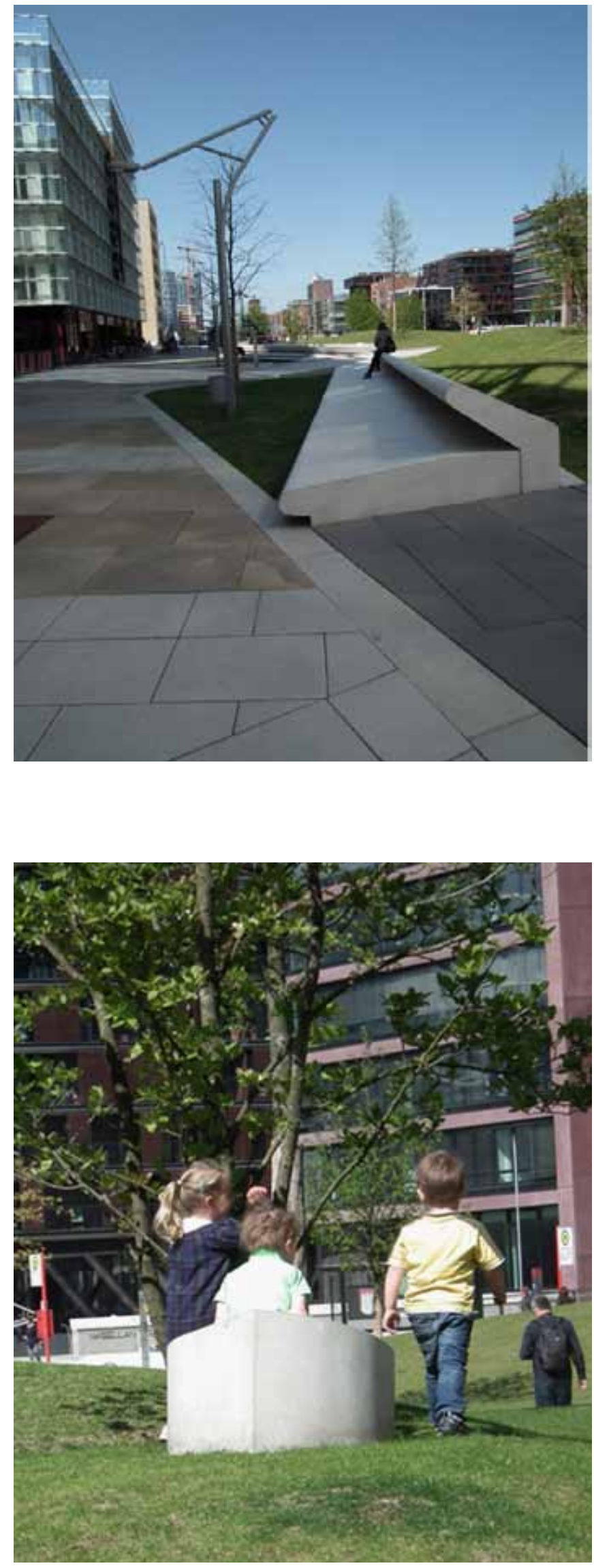

Figura 7: O desenho do mobiliário urbano é condizente com o relevo criado para a praça, e colabora na sustentação dos volumes de terra. Este equipamento urbano poderia ser denominado como um "banco linear", mas seu uso é diverso, tornando o espaço mais interessante. As luminárias se repetem em todo o projeto, e são inspiradas na leitura da paisagem dos grandes guindastes do porto, reforçando a identidade local do projeto. Foto da autora, maio/2012.

As figuras 8 e 9 ilustram o discurso de Benevolo (1993), quando enfatiza que os espaços livres apropriados à recreação e lazer devem se distribuir pela cidade, de forma que haja áreas verdes destinadas ao jogo e ao esporte, perto das residências.

Os bancos que surgem em meio ao gramado não são peças escultóricas, são equipamentos iguais aos que estão ao longo do caminho de pedestres, em percurso semipermeável.

Figura 8: Crianças brincando na praça. Foto da autora, maio/2012. 
Figura 9: Crianças utilizando os bancos da praça. Foto da autora, maio/2012.

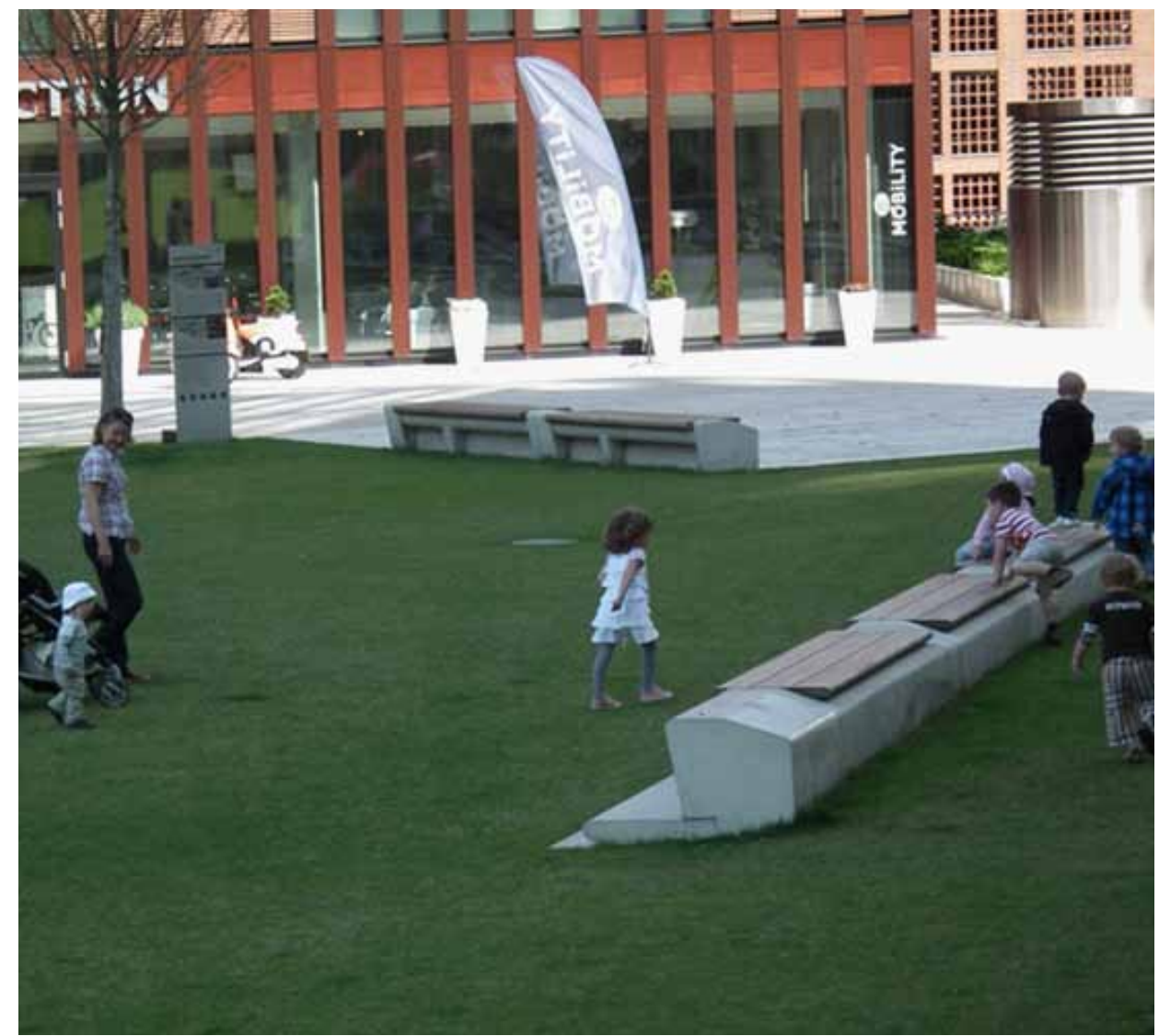

O posicionamento de bancos em meio ao gramado garante à população um acesso democrático ao espaço, estimulando o passeio sobre a grama, uma situação proibida em vários espaços verdes brasileiros.

Nas figuras 10 e 11, pode-se observar que o sistema de espaços públicos de HafenCity apresenta uma sequência de espaços livres e verdes, conceituados e apresentados por Llardent (1982, p. 151).

Sistemas de espaços livres: Conjunto de espaços urbanos ao ar livre destinados ao pedestre, para o descanso, o passeio, a prática esportiva e, em geral, o recreio e entretenimento, em sua hora de ócio;

Espaço livre: Quaisquer das distintas áreas verdes que formam o sistema de espaços livres;

Zonas verdes, espaços verdes, áreas verdes, equipamento verde: Qualquer es- 
paço livre no qual predominam as áreas plantadas de vegetação, correspondendo, em geral, ao que se conhece como parques, jardins ou praças.

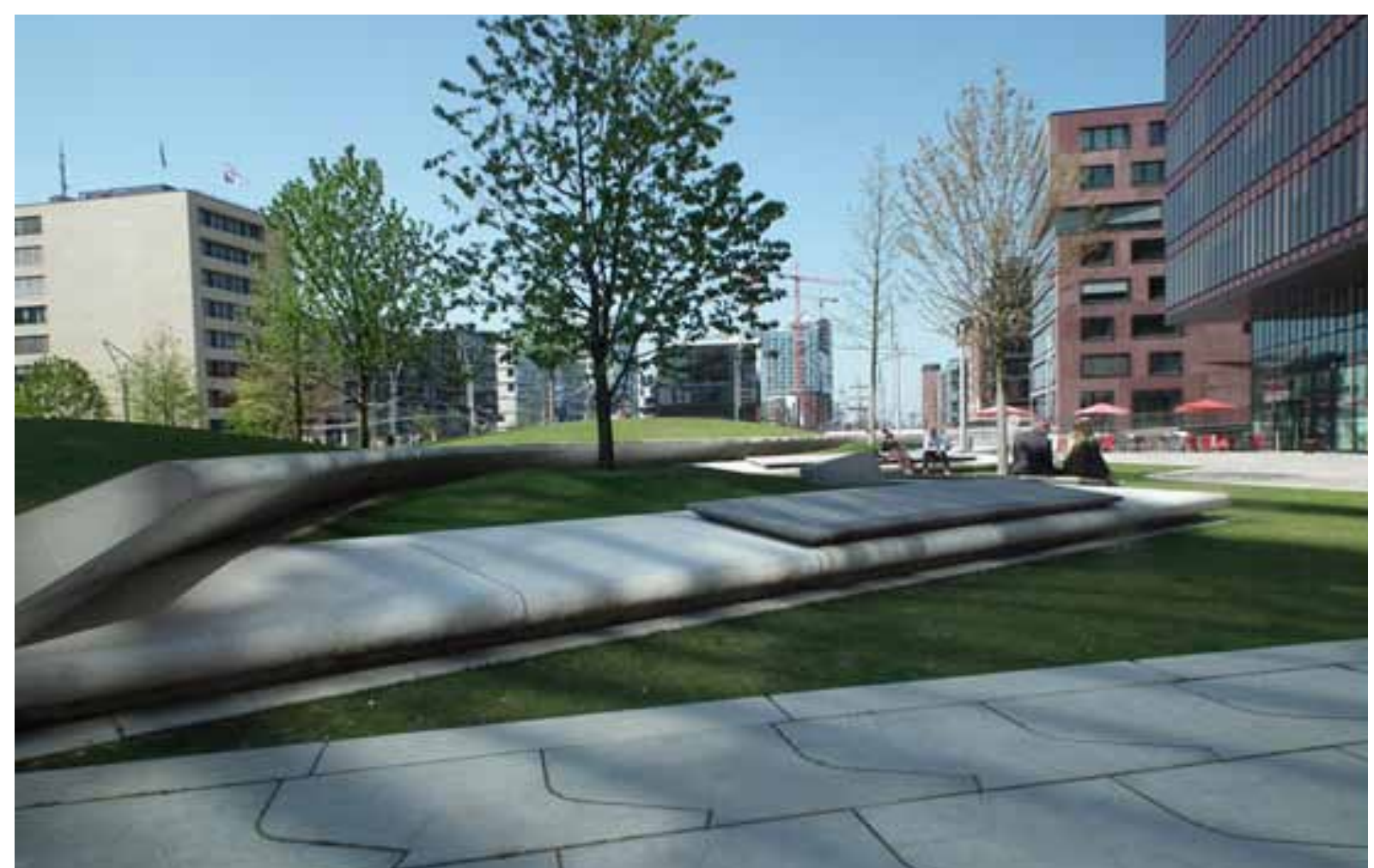

Figura 10: O piso semipermeável apresenta placas grandes, que o tornam confortável ao passeio do pedestre e facilitam os deslocamentos de pessoas com mobilidade reduzida. A estrutura que dá forma aos bancos lineares também organiza passeios e espaços de estar em diferentes níveis. Foto da autora, maio/2012.

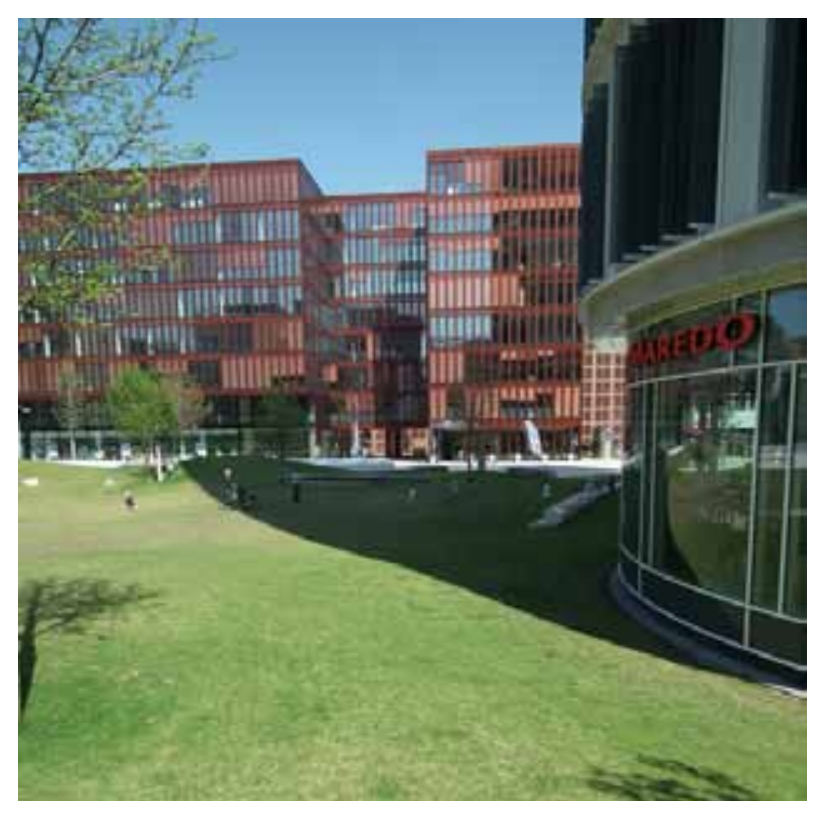

Para Milano (1988), as áreas verdes na cidade se dividem em dois grupos: áreas verdes e arborização urbana, pois a cobertura arbórea das áreas privadas pode desaparecer, mas a arborização urbana dos espaços públicos deve prevalecer, sendo, assim, de responsabilidade do poder público, a manutenção e gestão dos espaços verdes na cidade.

Figura 11: $O$ espaço público proporciona o distanciamento necessário para a observação da arquitetura na paisagem da cidade. Foto da autora, maio/2012. 


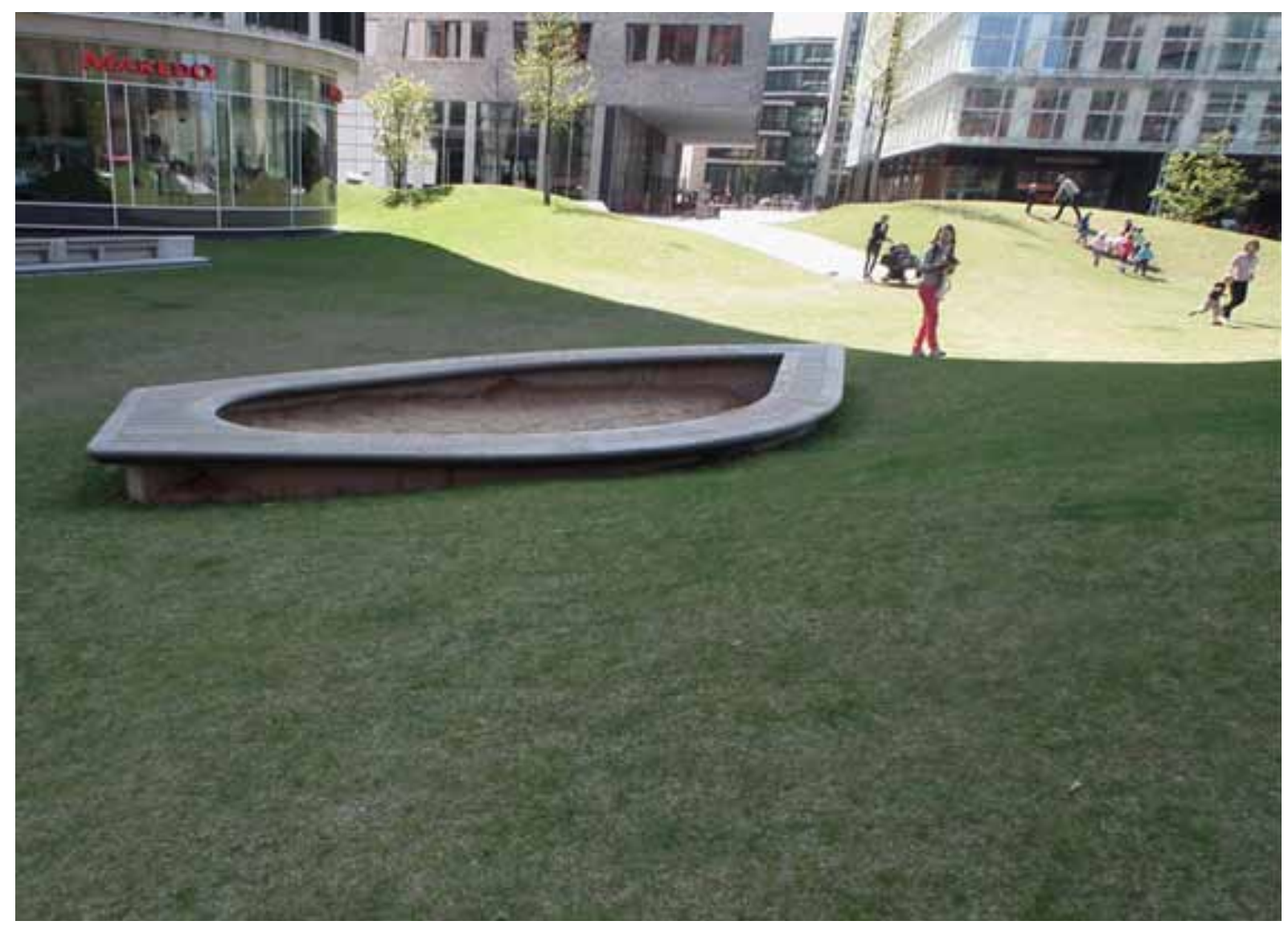

Figura 12: Em primeiro plano, tanques de areia, e, ao fundo, mulher com carrinho. Foto da autora, maio/2012.

Os tanques de areia aproximam crianças e adultos e têm um desenho interessante, que, apesar do ângulo agudo, está executado de forma adequada para assegurar a segurança necessária a todos os usuários do espaço.

A acessibilidade até alguns espaços é restrita, pois os caminhos existem até alguns pontos centrais da praça, mas, ainda assim, permitem o acesso às áreas verdes, tornando-as democráticas.

Entre o espaço em cota seca desta praça e os espaços em cotas de inundação, há um percurso de aproximadamente 800 metros, onde estão instalados um mirante e uma roda-gigante (ver figura 13).

Ainda em cota seca, estes equipamentos urbanos são muito interessantes, pois permitem a observação da cidade em uma perspectiva aérea, que também revela detaIhes interessantes do projeto urbano de HafenCity. 
A roda-gigante também funciona como elemento de referência urbana, pois, devido a suas magníficas dimensões, é vista em grande parte do percurso desenvolvido em cotas de possível inundação.

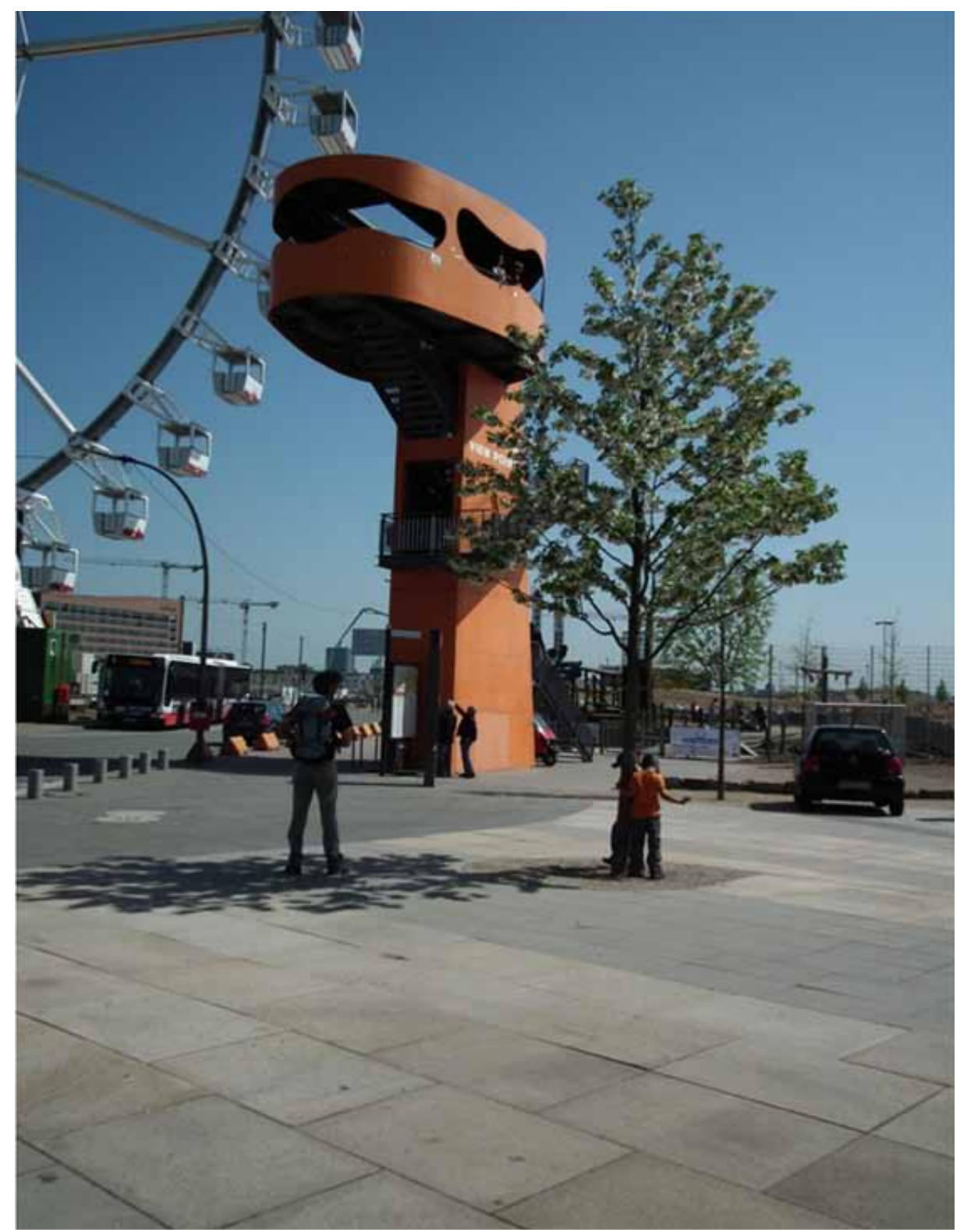

Figura 13: Em meio aos espaços públicos, surge um mirante, para que alguns desses espaços possam ser visualizados em seu conjunto de implantação. Foto da autora, maio/2012.

\section{MOBILIDADE DO ESPAÇO PÚBLICO: ACESSIBILIDADE ÀS DIFERENTES COTAS DE INUNDAÇÃO}

Os espaços públicos mais próximos às águas são os mais suscetíveis de inundar-se. Por essa razão, apresentam menor quantidade de espaços permeáveis, mas, ainda assim, as árvores estão presentes. 


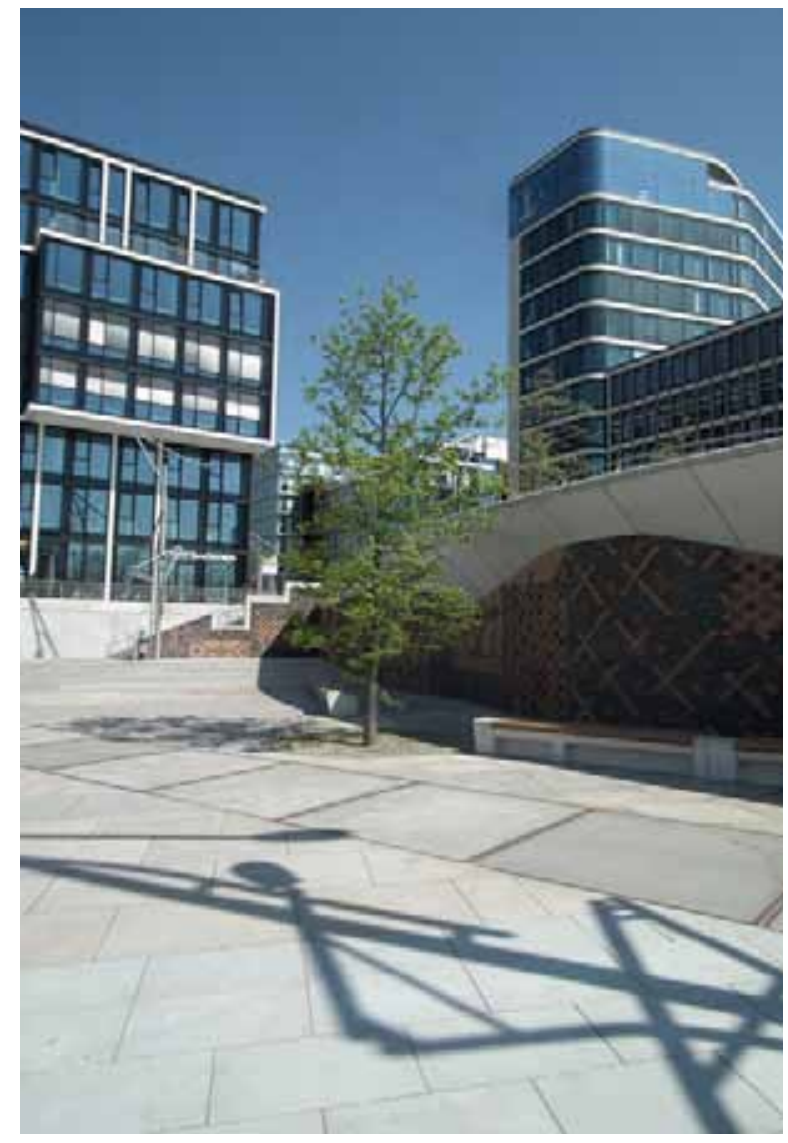

Figura 14: Espaço de estar na primeira cota de inundação. Foto da autora, maio /2012.

Nas figuras 15 e 16, um mesmo símbolo, em forma de gota, aparece junto à iluminação embutida nos bancos.
Figura 15: Os espaços de estar com vista para as águas apresentam diferentes possibilidades, para sentar ou deitar sobre decks de madeira. Foto da autora, maio /2012. 

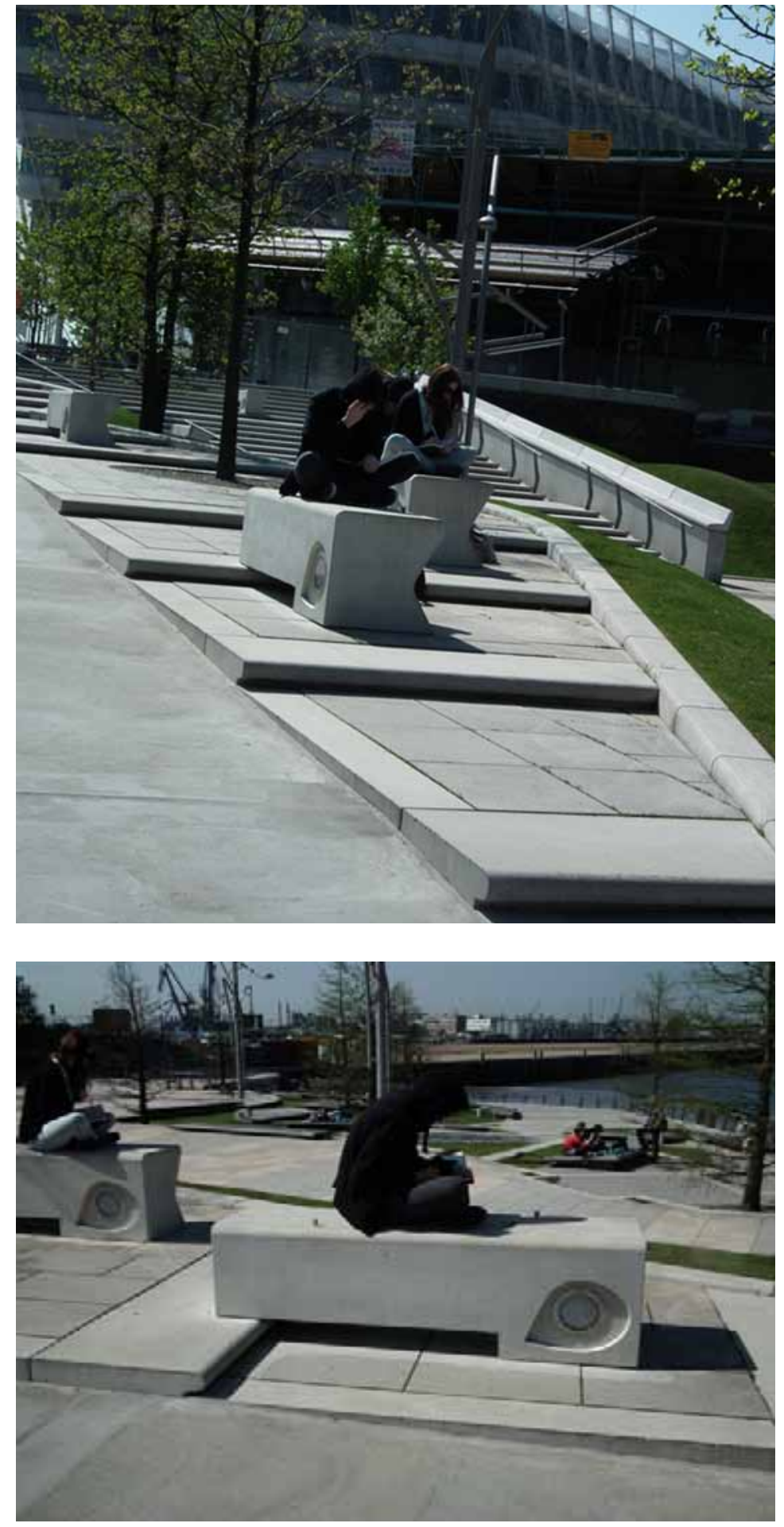

Figura 16: Bancos em meio às escadas são comuns em HafenCity. Foto da autora, maio/2012.

Figura 17: Na figura 16, este mesmo banco, com poucas adaptações, está reposicionado, com função de mesa, em meio às escadas. Foto da autora, maio/2012.

Esta gota se repete em tanques de areia, da figura 12, e também nas golas das árvores, parece ser uma referência de identidade do projeto. Em uma leitura lúdica, esta forma pode ser uma "gota", mas também lembra a "quilha das embarcações". O importante é a identidade visual e paisagística que confere aos diferentes espaços, unindo-os pela delicadeza expressa nos detalhes temáticos e técnicos. 
Figura 18: $O$ desenho do piso conduz sutilmente o olhar para a área de estar. Foto da autora, maio/2012.

Em HafenCity, nomes como Richard Meier, David Chipperfield, Rem Koolhaas, Zaha Hadid, Herzog \& deMeuron (ver figura 19), Hadi Terrani e Stefan Behnisch assinam obras emblemáticas, e responsáveis, em parte, pelo sucesso do empreendimento, tanto para turistas, como para empresários.

Figura 19: As luminárias são uma releitura da imagem dos guindastes portuários, mas também se confundem com os guindastes da construção civil, na paisagem da cidade em reconstrução. Foto da autora, maio/2012.
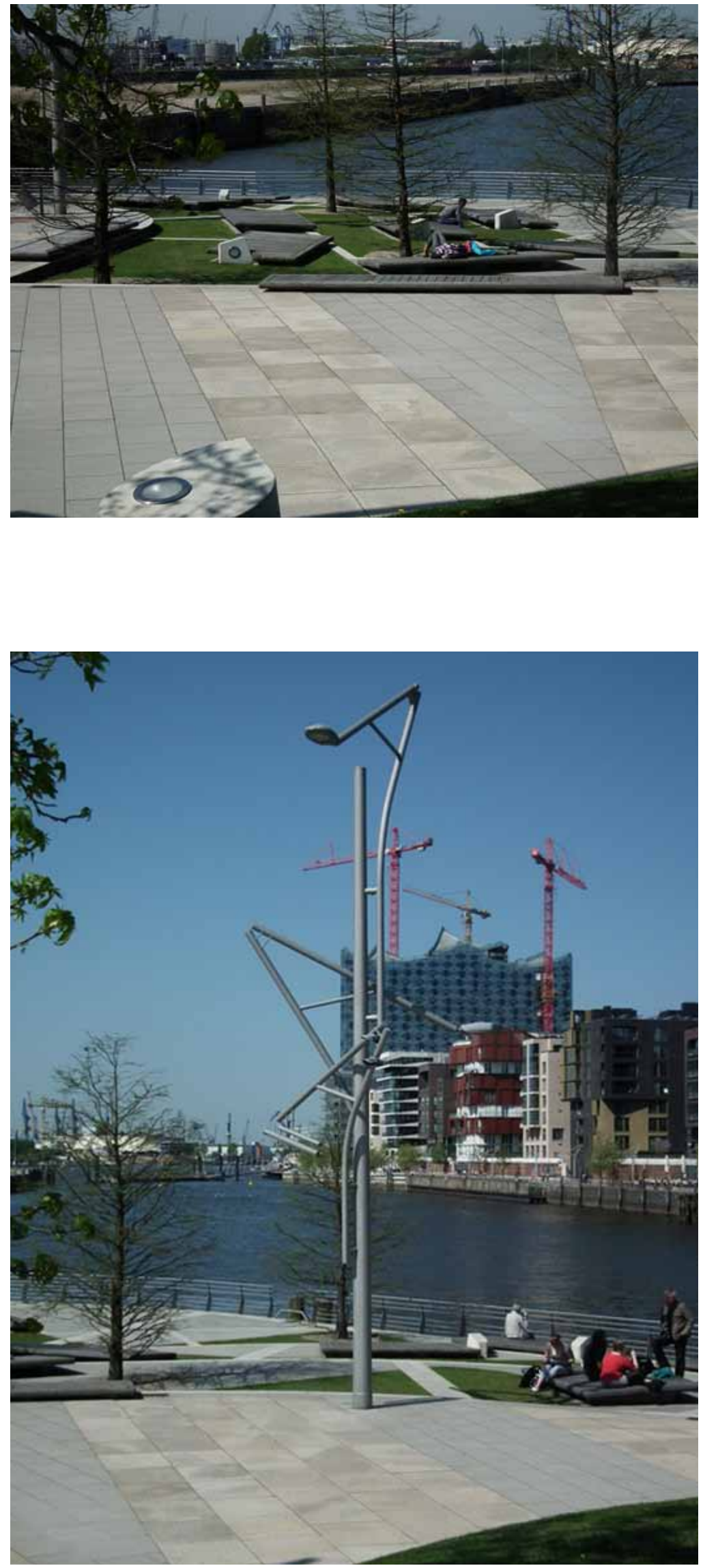
As figuras 20, 21 e 22 apresentam um percurso junto às águas, com espaços de estar, passeio e comércio, ao longo dos quais se desenvolve um mosaico em diferentes tonalidades de tijolo.

Na região mais antiga de HafenCity, todos os antigos edifícios portuários têm tijolos bem escuros, devido ao material e à forma de produção característica da região.
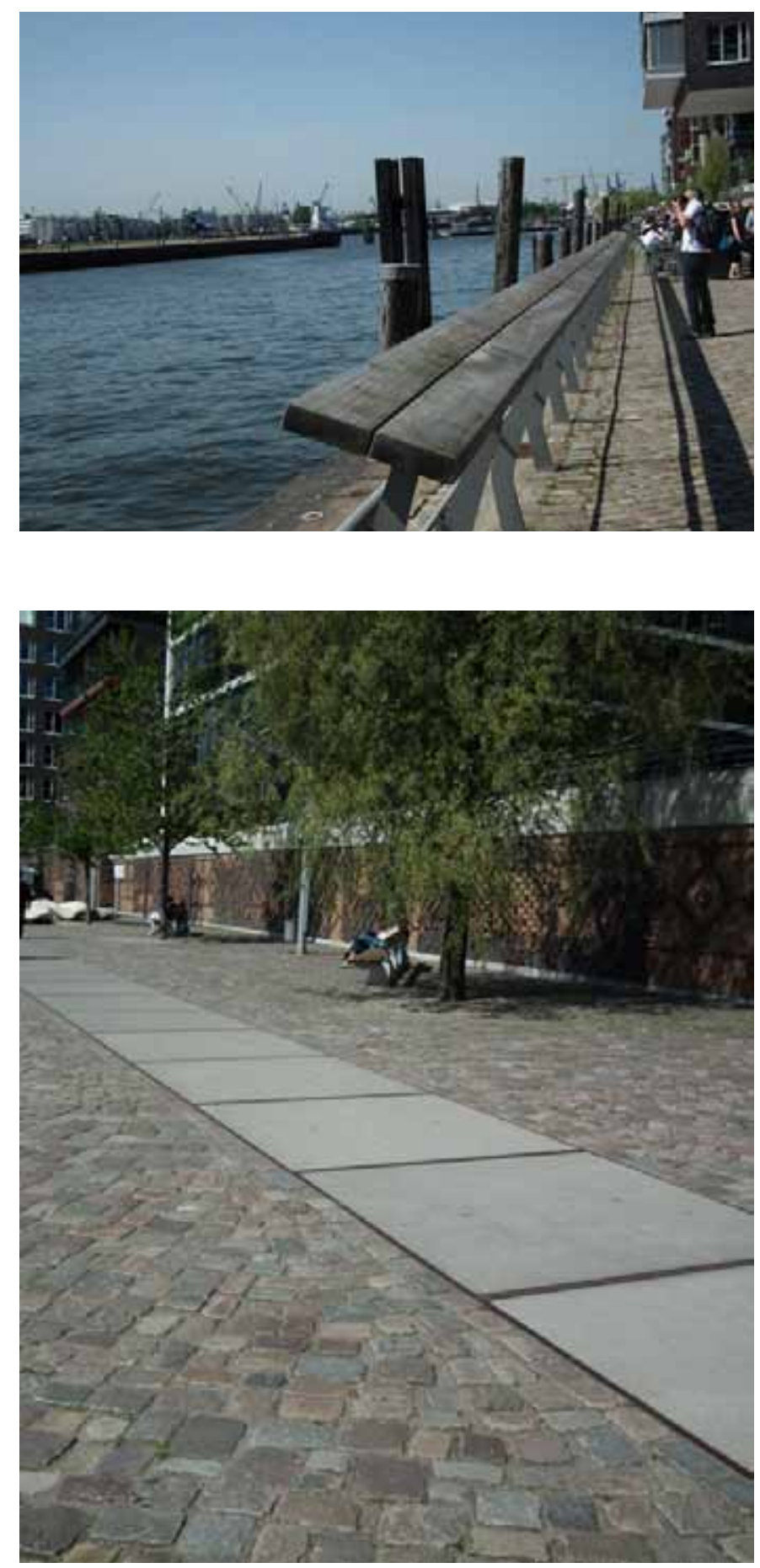

Figura 20: Belvedere para o porto. Foto da autora, maio/2012.

Figura 21: Ao longo do belvedere para o porto, há espaços de estar, com bancos, árvores e um painel de tijolos, que acompanham todo o percurso. O percurso, demarcado em material de menor atrito, proporciona melhor deslocamento de cadeirantes e pessoas com mobilidade reduzida. Foto da autora, maio/2012. 
Figura 22: Alguns espaços de estar têm equipamentos com desenho especial. Foto da autora, maio/2012.

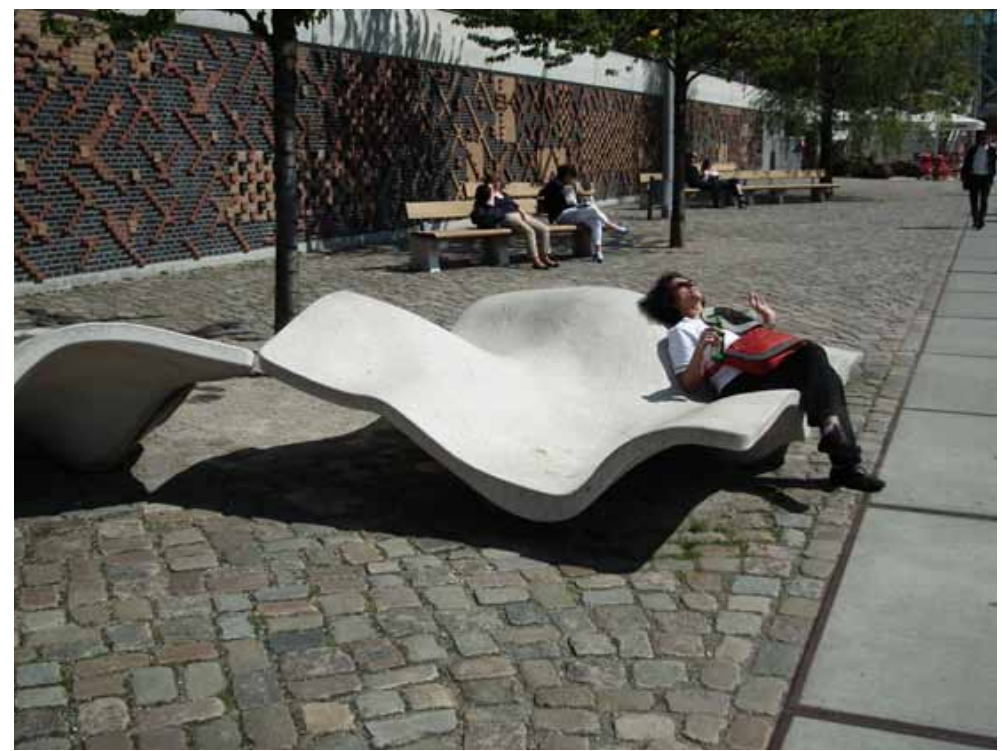

Estes bancos (figura 22), com um desenho que se assemelha a conchas, se inserem no espaço público com um caráter de "escultura", mas com função de banco, e promovem um interesse especial por este espaço de estar, que está tangente à rota de circulação do projeto.

A figura 22, nas palavras de Milton Santos (1985), é um exemplo de como podem ser identificados, no espaço público, alguns elementos de permanência e de passagem, os quais sinalizam que há uma abordagem do espaço que considera tanto os espaços de estar, quanto os fluxos que o percorrem.

Logo após estes bancos em forma de ostras, surgem cafés e restaurantes, que mantêm suas mesas ao longo do projeto, configurando um uso "semipúblico" do espaço, conforme se vê na figura 23.

Figura 23: Mesas de bares e restaurantes ao longo do percurso. Ao fundo, observa-se grande mobilidade, característica de um espaço democrático. Foto da autora, maio/2012.

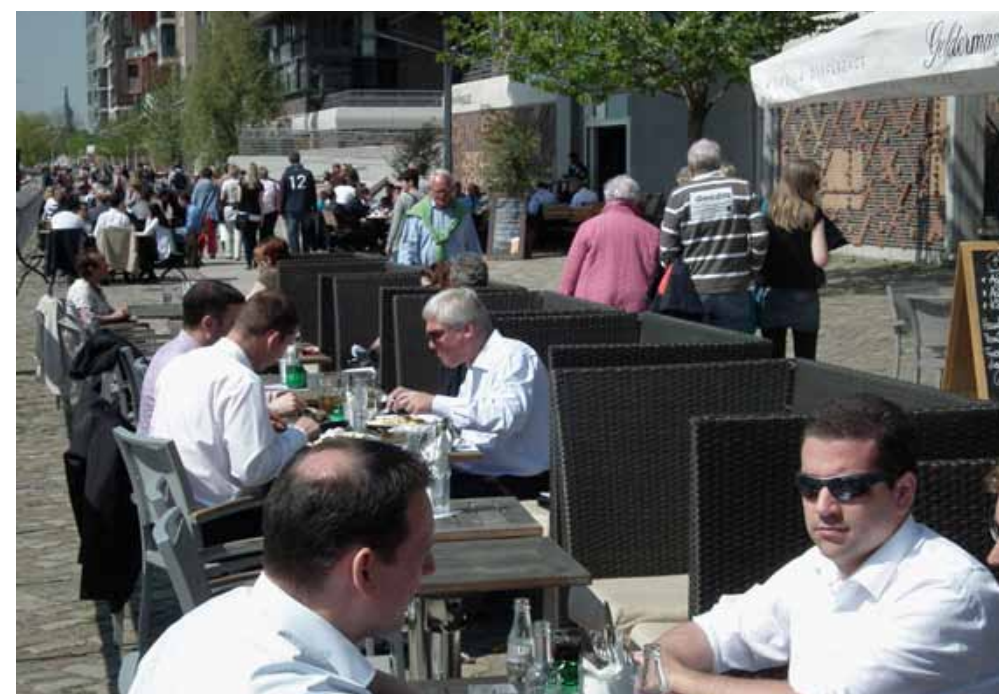


Para Vieira (1997), a ocupação plural do espaço público pode trazer desequilíbrios na relação entre os atores sociais e o sistema político, com o predomínio da sociedade política, que passa a selecionar a inserção das associações civis no Estado, conferindo-lhes um status semipúblico.

HafenCity se vale da inserção de usos privados em espaço público e, segundo Avritzer (1996), ocorre, no espaço, "um hiato entre as formas de ocupação do espaço público e as formas de legalização da vida associativa e da relação entre sociedade civil e sociedade política".

Os circuitos definem-se como "percursos urbanos", por permitirem a mobilidade de pessoas e veículos. Podem ser exclusivamente para peões (os percursos pedonais), mistos (para peões e veículos) ou exclusivamente para veículos, incluindo também espaços reservados ao estacionamento de veículos. Este tipo de espaço público torna-se cada vez mais presente no espaço urbano-metropolitano, uma vez que as deslocações adquirem uma maior importância e se tornam cada vez mais precoces no seio familiar - passamos todos cada vez mais tempo nos espaços afectados ao transporte - e, muitas vezes, a sua qualidade não tem em conta o ponto de vista do automobilista ou do utilizador dos transportes. (MATOS, 2010, p. 22)

Após este uso do espaço público, que pode ser considerado "elitizado", pois confere $\mathrm{o}$ uso de alguns equipamentos apenas àqueles que estão se servindo dos restaurante, surgem espaços também de alimentação, porém de uso público (fotos 24 e 25$)$

As figuras 24 e 25 ilustram bem como a população se apropria dos espaços de estar existentes no espaço público. Algumas pessoas fazem lanches nos espaços de estar, em meio às escadas, de frente para as águas.

Nas palavras de Salgueiro (1998, p. 228):

"O aumento da mobilidade e a diversidade de contactos abertos aos indivíduos permite-lhes, não só, desmultiplicarem-se por diversos papéis e identidades, mas também pertencerem a diversas redes fragmentadas por diversos lugares afastados" 
Estes espaços estão em cotas de inundação, o que se pode perceber pela presença de escadas e rampas, que sobem nove metros e são visíveis nas fotos. Entretanto, executados com excelente qualidade, não se configuram como escadarias em "zonas de fronteira", mas como espaços projetados para abrigar o desenvolvimento de relações democráticas e cidadãs.

Figura 24: Espaço de estar em meio à escada, em primeiro plano, e mobilidade entre os diferentes níveis do projeto, marcada pela presença das rampas em segundo plano. Foto da autora, maio/2012.

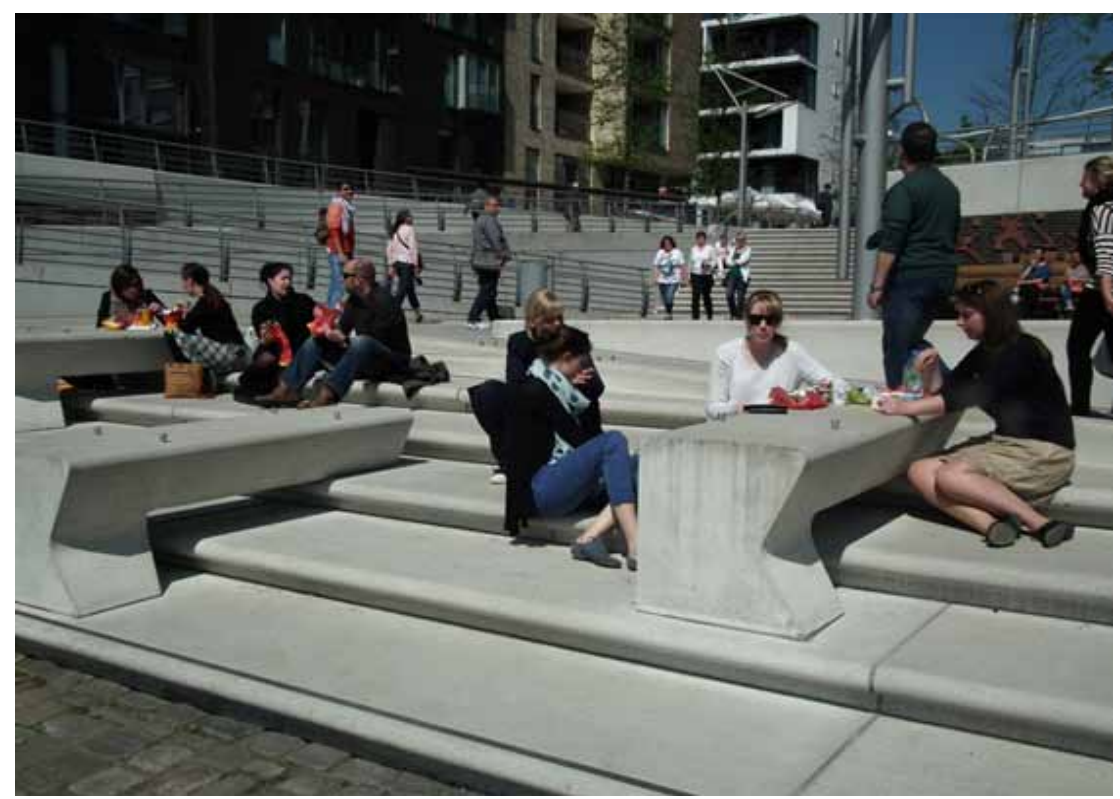

Segundo Lefèbvre (2001), as cidades são centros da vida social e política, local onde se acumulam riquezas, conhecimento, tecnologias, obras de arte e monumentos. Desta forma, a reestruturação da cidade, por meio de um conjunto de espaços públicos interligados, fortalece as relações urbanas e humanas.

Figura 25: Mesas em meio às escadas são utilizadas para lanches ao ar livre, na hora do almoço. Ao fundo, as rampas necessárias para acessar os níveis superiores do projeto urbano. Foto da autora, maio/2012.

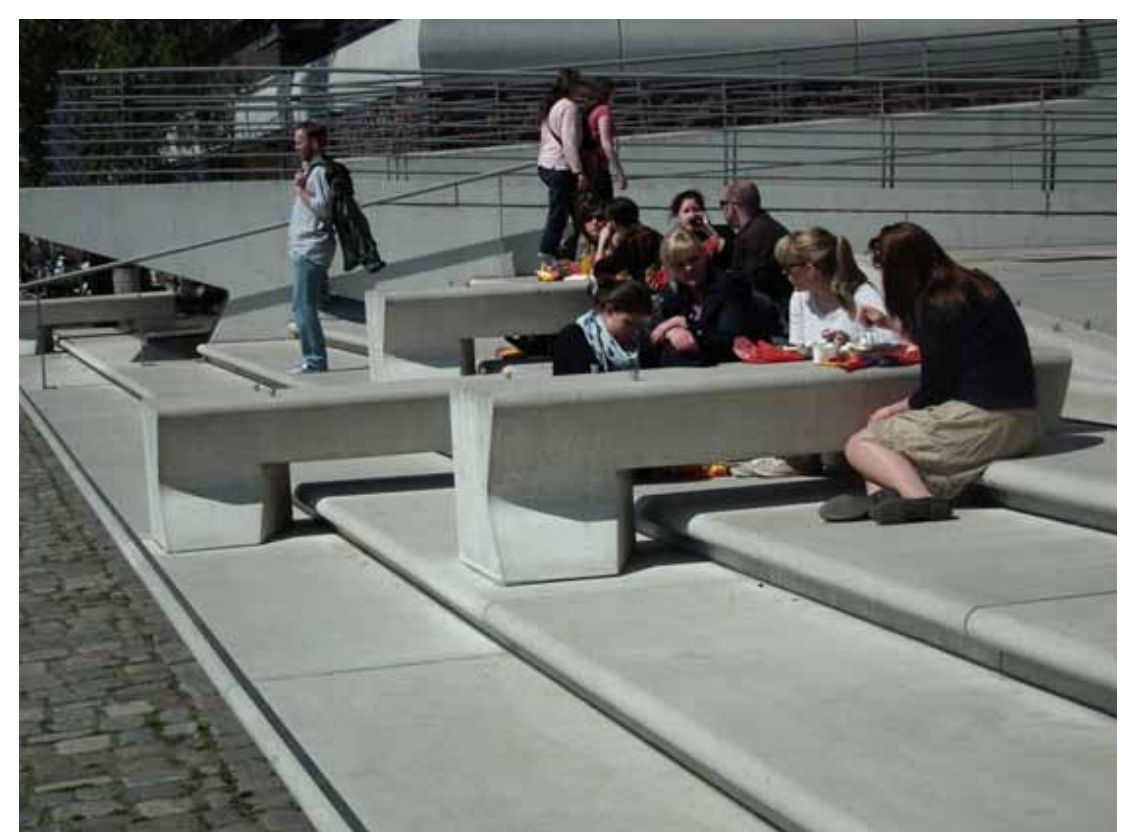


Se observados isoladamente, estes comporiam mais um exemplo de projeto de espaço público que fragmenta o espaço, suas funções e usos. No entanto o percurso à margem das águas interliga todos os espaços em uma perspectiva urbana, onde a paisagem é o grande elemento de integração, pois todos os espaços desfrutam democraticamente da mesma paisagem, como se vê nas figuras 26 e 27.

A roda-gigante, ao fundo, dá a dimensão da escala do espaço público e atua como elemento de referência da paisagem urbana. As edificações se abrem, em terraços e janelas, para a paisagem das águas da cidade de Hamburgo.

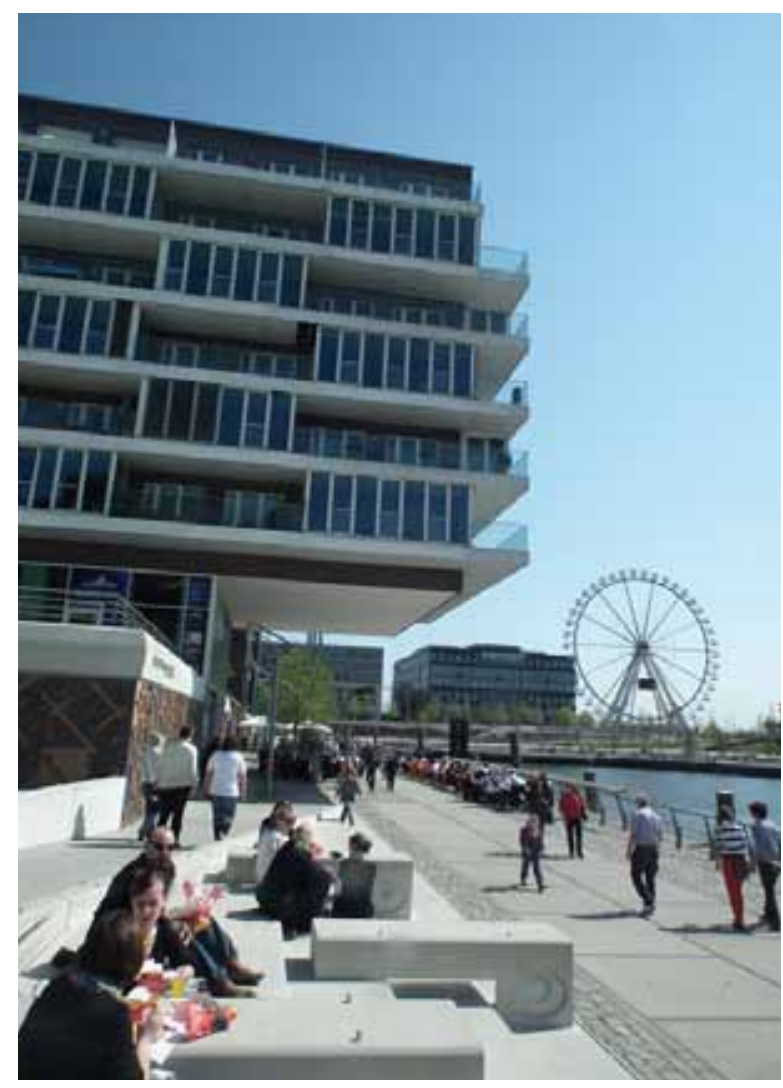

Figura 26: Espaço público de estar, em meio à escada, em primeiro plano, e espaços de uso privado, junto às águas, em segundo plano, ambos parcialmente acessíveis aos cadeirantes e pessoas de mobilidade reduzida, presentes nesta figura, são características de espaços onde a acessibilidade atitudinal é promovida pela acessibilidade arquitetônica, conferindo aos espaços públicos alta mobilidade. Foto da autora, maio/2012.

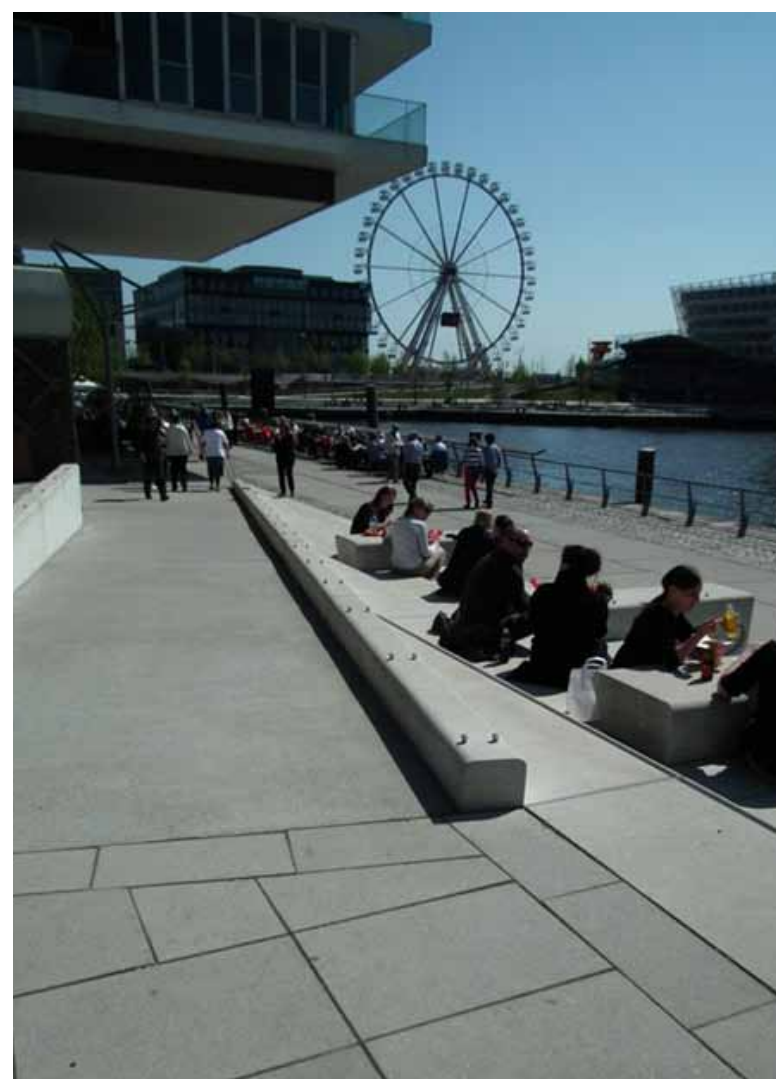

Figura 27: A arquitetura da cidade, com suas sacadas e janelas, volta-se para a paisagem da cidade e o eixo de circulação à beira das águas. As rampas tornam acessíveis as cotas mais baixas do conjunto de espaços públicos e estão integradas ao desenho do espaço, participando da paisagem do local de forma delicada e elegante, conferindo dignidade aos cadeirantes e pessoas com mobilidade reduzida. Ao fundo, a roda-gigante e o mirante. Foto da autora, maio/2012. 
Após a sequência de espaços de estar, o percurso apresenta nova transição de nível, como pode ser observado nas figuras 28 e 29.

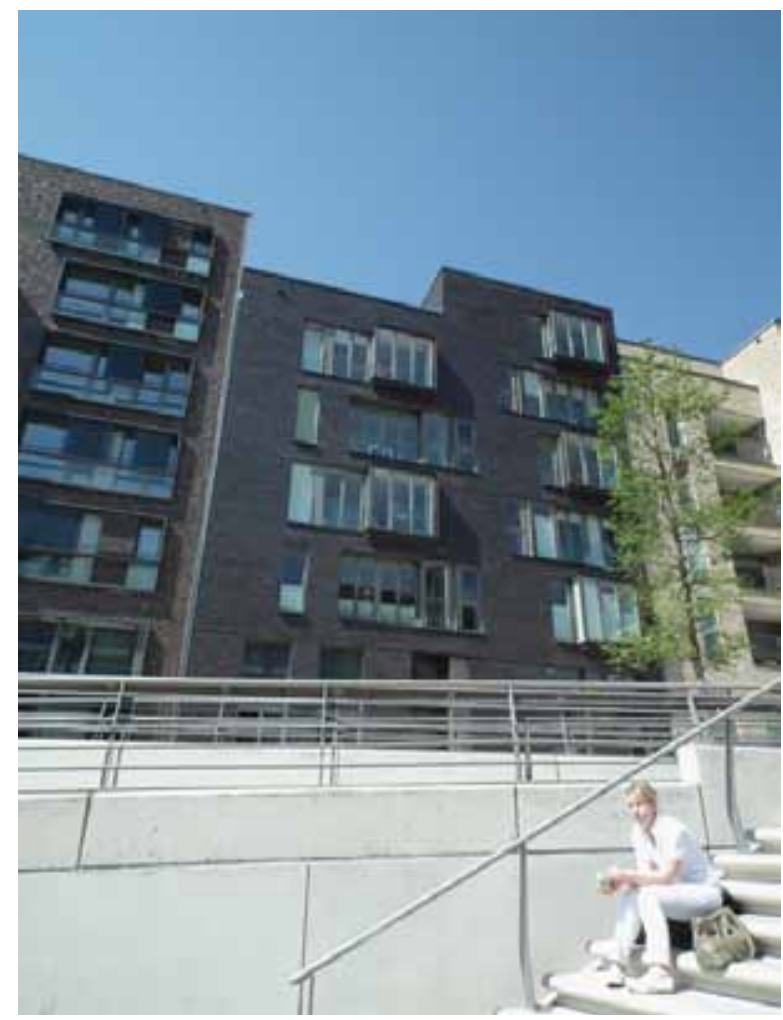

Figura 28: A presença dos tijolos escuros, característicos da região portuária de Hamburgo, em contraste com o projeto de reestruturação do espaço público. As rampas de acesso aos diferentes níveis compõem o cenário de aproximação do homem com a natureza. Foto da autora, maio/2012.

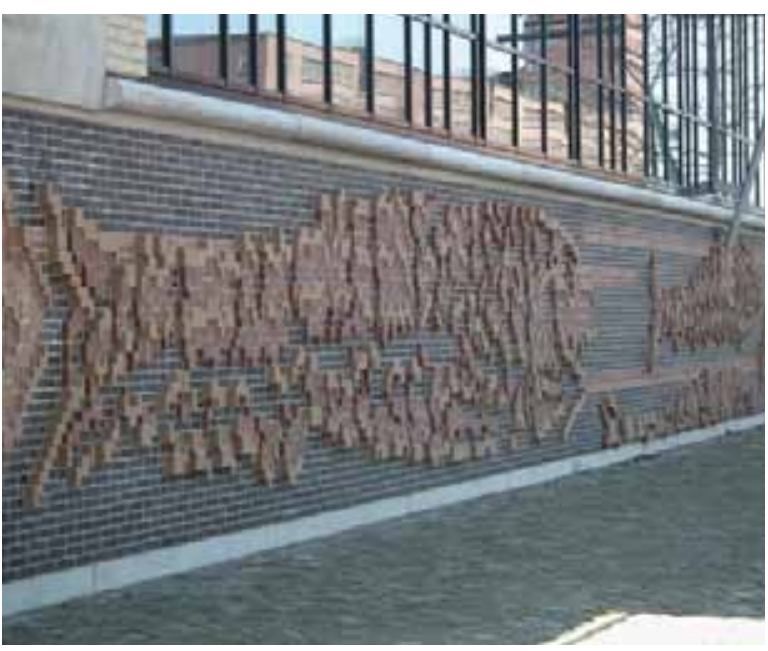

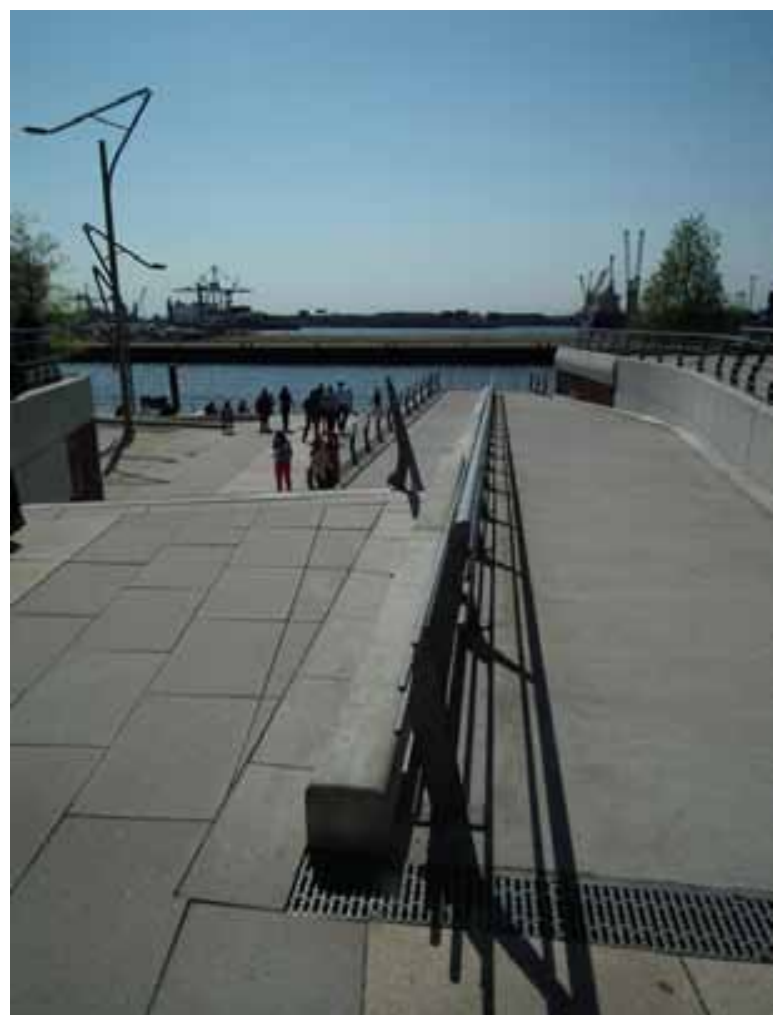

Figura 29: Transposição entre as cotas inundáveis e as cotas secas da cidade, feita por rampas. Foto da autora, maio/2012.

Mais adiante, outro percurso ao longo das águas apresenta os painéis de tijolos que acompanham todo o trajeto.

Figura 30: Painel de tijolos, que acompanha o trajeto e dá frente para a figura 32. Foto da autora, maio/2012. 


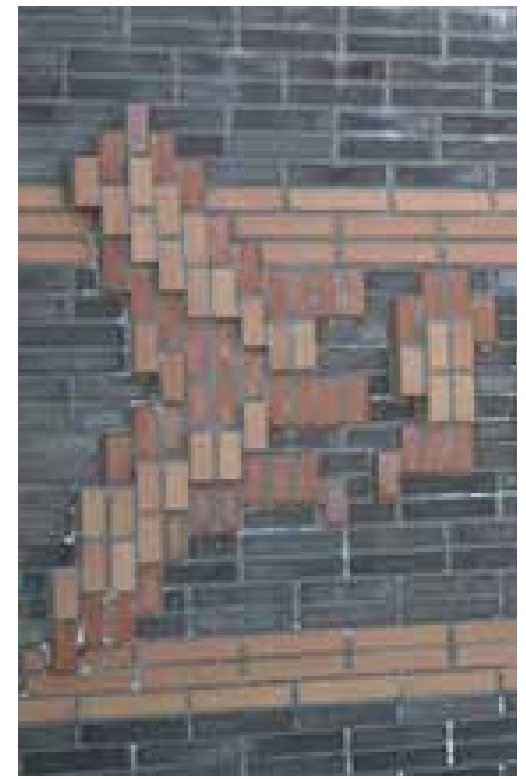

Figura 31: Detalhe da composição dos tijolos do painel. Foto da autora, maio/2012.

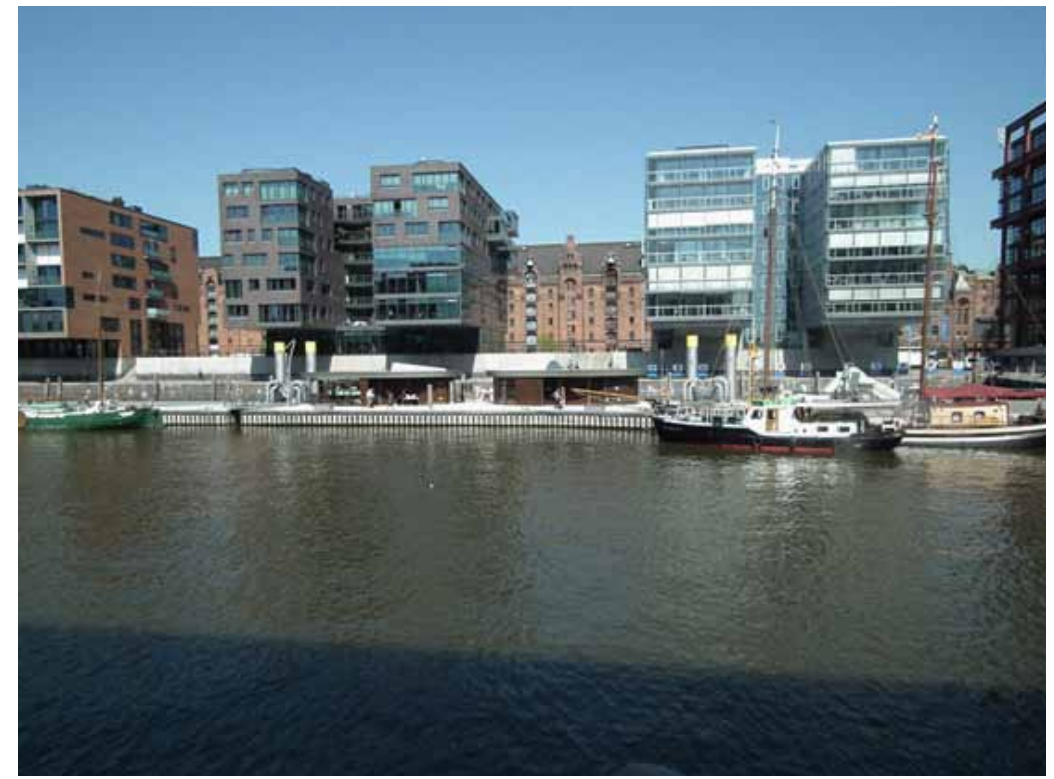

Figura 32: Paisagem da cidade, nova e antiga, que se observa no passeio ao longo do painel de tijolos, na margem oposta. Foto da autora, maio/2012.

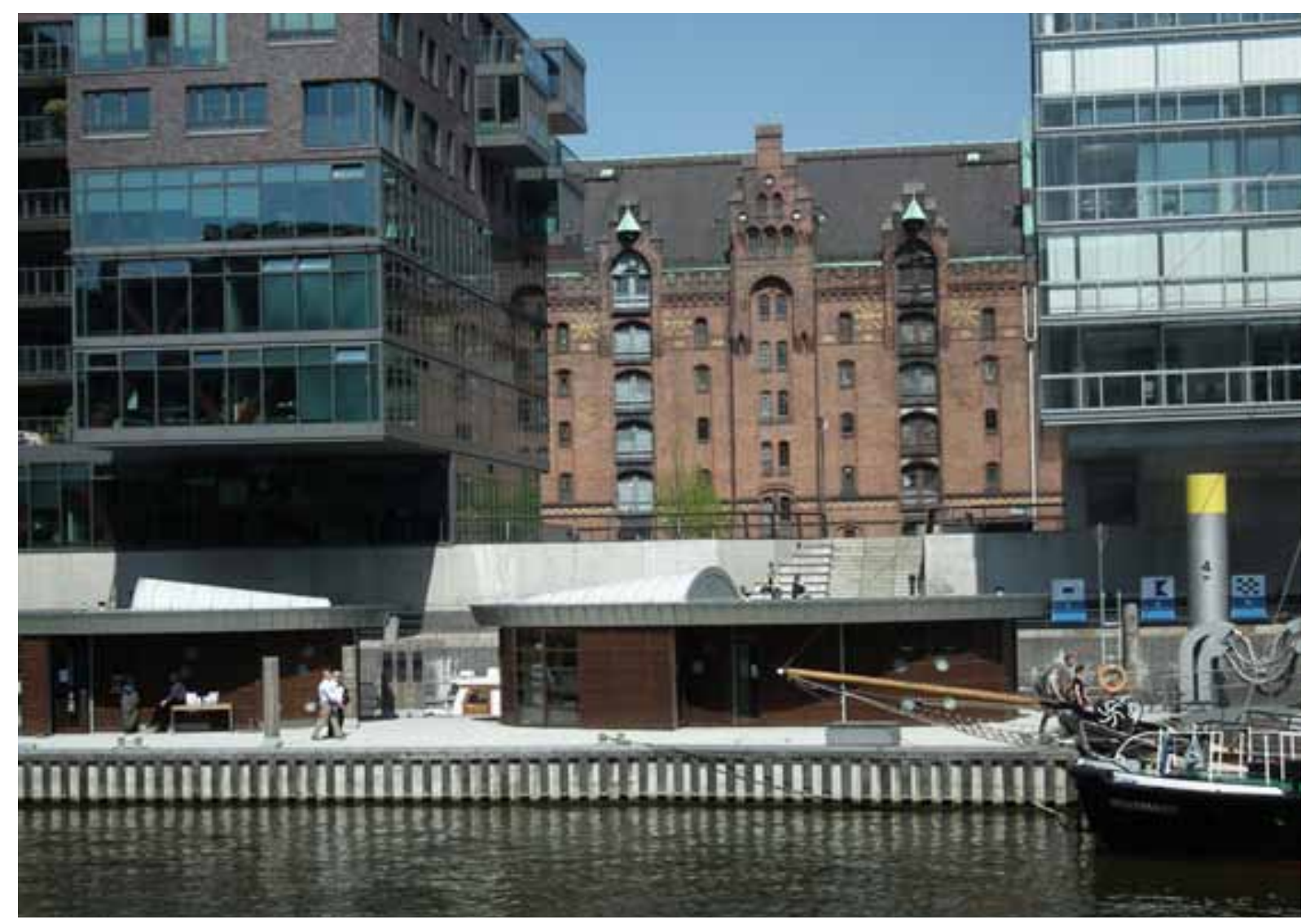

Figura 33: Contraste entre a cidade histórica e a arquitetura contemporânea, tendo em primeiro plano a complexa mobilidade de Hamburgo. Foto da autora, maio/2012. 
O tijolo é um material típico e tradicional da arquitetura de Hamburgo e norte da Alemanha, região que pertence, em grande parte, ao estuário do rio Elba, onde abunda o solo denominado marsch ${ }^{1}$, no qual não há predominância de rochas. Desta forma, a indústria de tijolos se aprimorou.

Na paisagem de Hamburgo, observa-se que as igrejas góticas, desde a Idade Média, foram executadas em tijolos, arquitetura denominada Backsteingotik2, e a arquitetura contemporânea de Hamburgo mantém relação com a paisagem da cidade e a história local, ao utilizar os tijolos tradicionais da região.

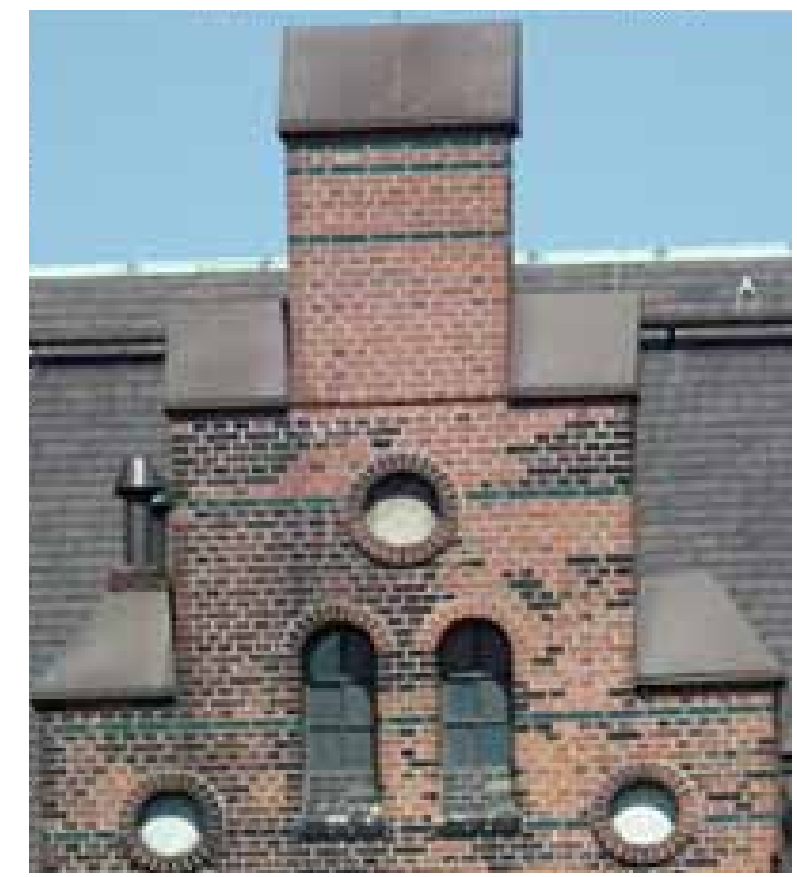

Figura 34: Detalhe dos tijolos da arquitetura típica de Hamburgo, com tonalidades diferentes, devido ao material e à queima, características do processo de produção. Foto da autora, maio/2012.

A partir da observação deste detalhe da arquitetura, fica evidente a inspiração utilizada para o desenho e a produção dos painéis, que se apresentam em muitos pontos do projeto urbano de HafenCity.

Figura 35: $O$ desenho de piso que abre-se para a escada é simples e interessante, pois indica fluxos e inclui vegetação com gola adequada para seu desenvolvimento. Os materiais utilizados no piso também sempre são adequados, ou seja, não escorregam e permitem o passeio seguro, foto da autora maio/2012..

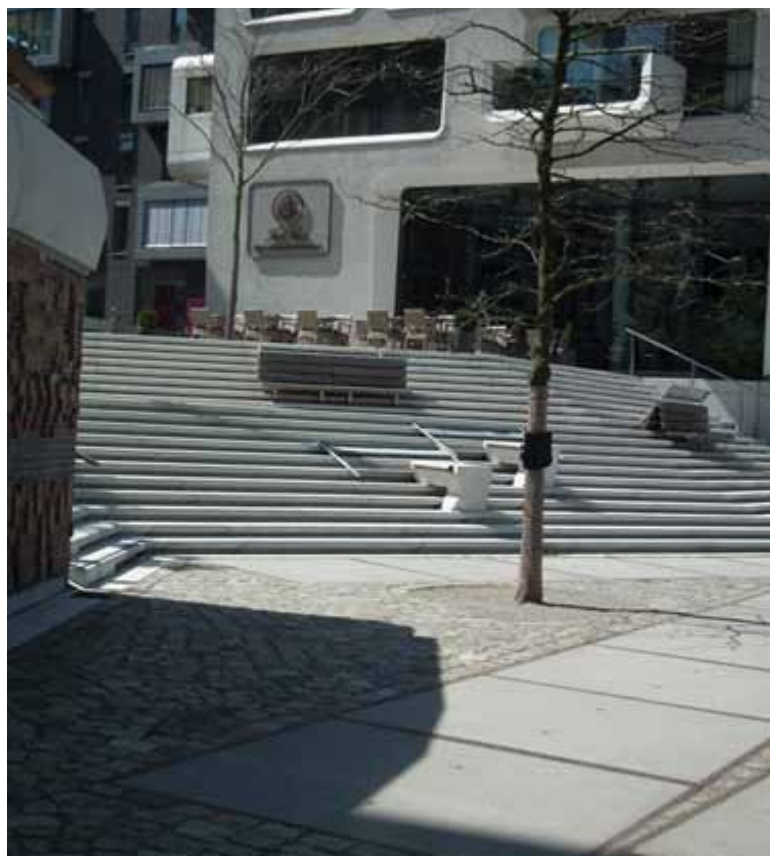

2 Marsch significa terreno pantanoso, e é a denominação de um tipo de solo, excelente para agricultura.

3 Backsteingotik significa gótico do tijolo. 


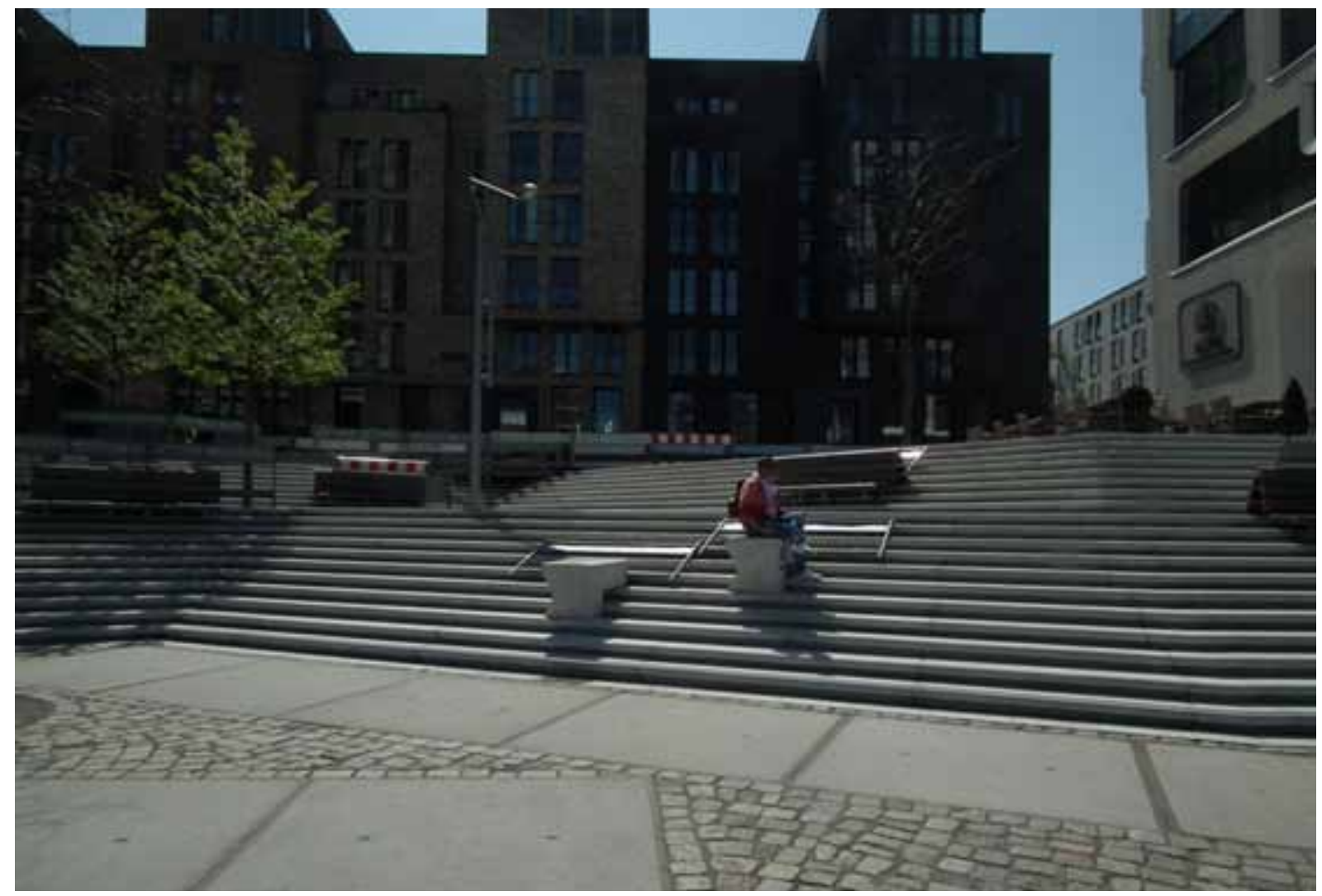

Figura 36: As escadas, necessárias à transposição entre as cotas inundáveis e secas, se convertem em espaços de estar, com a instalação de bancos e mesas em meio aos degraus. É interessante observar que esta paisagem "limpa" se deve a muitos fatores, entre eles, a possibilidade de uma escada deste porte não precisar de corrimão. Isto se deve a uma legislação diferente e à qualidade e conforto da escada. É importante ressaltar que a acessibilidade se faz aos patamares e níveis, porém não há hipocrisia em pensar espaços acessíveis em meio às escadas. Foto da autora, maio/2012.

Se considerarmos os aspectos técnicos, HafenCity tem tudo calculado. Com uma rede de passeios de pedestres interligados acima oito metros do nível do mar, garagens à prova d'água e sem residências no térreo dos edifícios, o bairro está preparado para enchentes. Assim como está se armando para o acesso da área a partir de linhas de metrô e ônibus. Ao mesmo tempo em que o bairro se afasta verticalmente da água, ele entra em contato direto com praças formadas por degraus, platôs e rampas que vão suavemente integrando o espaço altamente densificado com as águas do rio, criando áreas de contemplação e descanso. Contemporaneu\#04, p. $48^{4}$

4 Revista Contemporaneu, lançada em 2010, apenas em formato digital, disponível em http://www.contemporaneu.com.br/p/revista.html, acesso em 10/09/2012. 


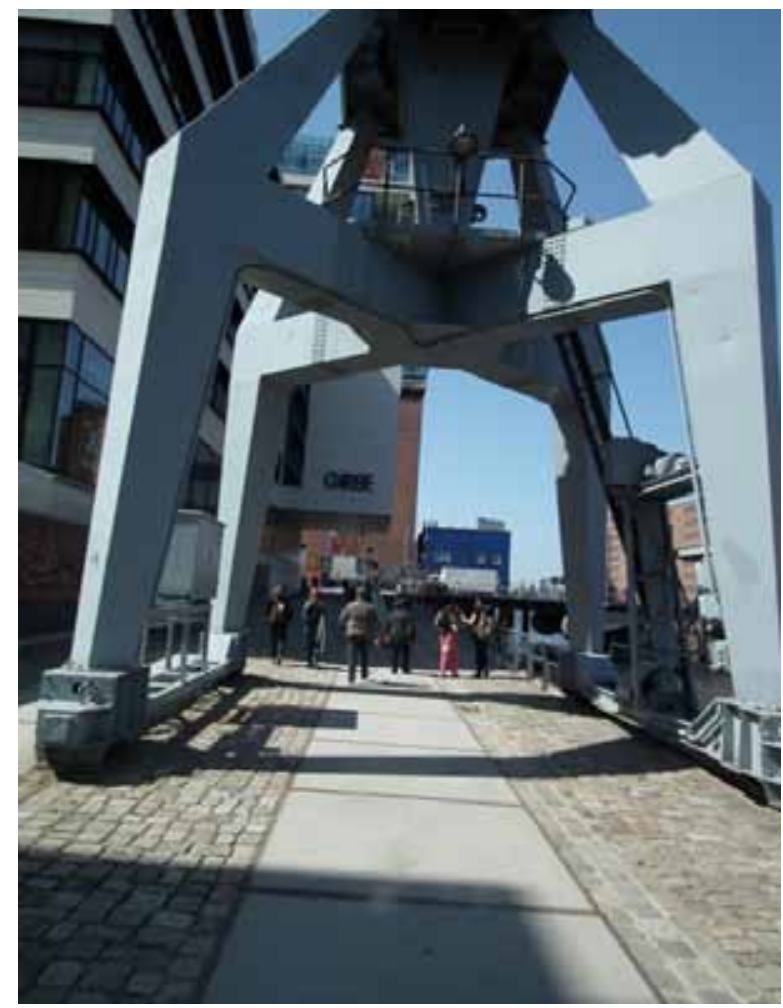

Figura 37: Os guindastes portuários surgem em meio ao desenho dos espaços públicos, fortalecendo a identidade do local e valorizando um percurso acessível a todos. Foto da autora, maio/2012.

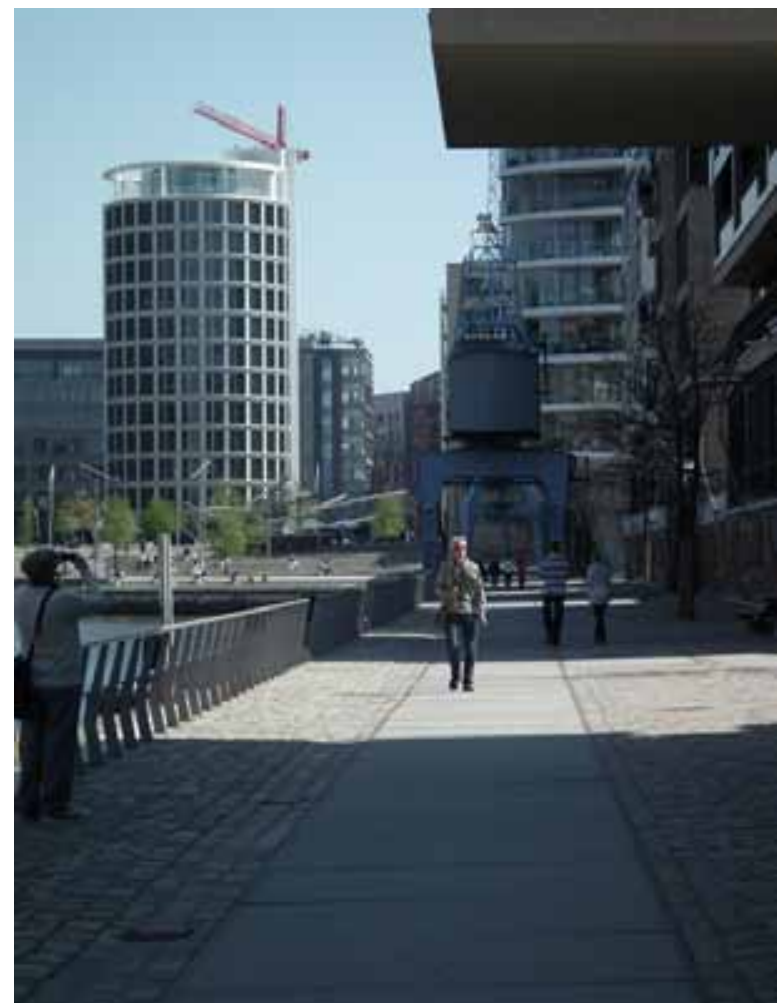

Figura 38: Os guindastes portuários são incorporados ao desenho do espaço público, como elementos estruturadores do percurso à beira das águas. Foto da autora, maio/2012.

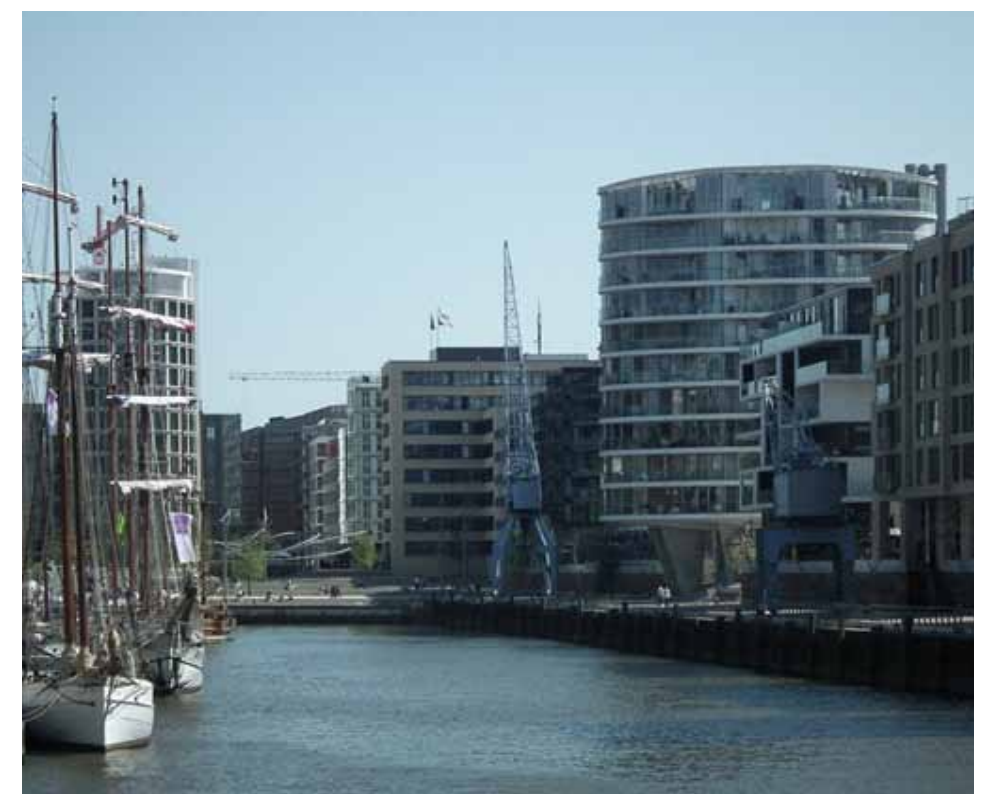

Figura 39: Os guindastes portuários permanecem na paisagem da cidade e se constituem como elementos referenciais do espaço público. Foto da autora, maio/2012.
A paisagem de HafenCity valoriza de todas as formas a história desta região portuária e sua complexa mobilidade, incorporando materiais e elementos que fortalecem a identidade local. A valorização das águas cria uma agradável e contemporânea paisagem para a cidade de Hamburgo. Para que os espaços urbanos sejam democráticos, é necessário que também sejam acessíveis a todos. 


\section{HAMBURGO VS. SÃO PAULO.}

O Plano Diretor Estratégico para o município de São Paulo (PDE), aprovado em 2002, traz novas perspectivas para a área urbanizada da cidade, para as áreas às margens dos rios e córregos, pois estabelece extensas áreas denominadas "operações urbanas". No entanto o desenho da cidade junto aos corpos hídricos não contempla as reais possibilidades de inundação, nem tampouco áreas de lazer que valorizem a preservação da relação do homem com a natureza.

A gestão do território ribeirinho deve ser efectuada com a compreensão das suas características e dos seus valores intrínsecos de modo a impulsionar a realização de actividades, do turismo, bem como a preservação e o uso sustentável dos recursos ali existentes. (ROSA, 2011, p. 38)

No entanto não se apoia no planejamento ambiental ou no desenho ambiental, como ferramentas importantes para a melhoria da qualidade de vida na cidade, e/ou para o estabelecimento de metas de desenvolvimento econômico.

HafenCity, ao contrário, se coloca como uma cidade que planeja seus espaços urbanos de acordo com suas potencialidades de crescimento econômico, o que mantém um equilíbrio social e vitaliza as questões culturais.

É muito importante observar que, pelo que foi pesquisado in loco, a reformulação urbana não tem necessidade de atingir índices urbanísticos, mas sim de impregnar, com boa qualidade de vida e boa qualidade ambiental, toda a rede de espaços públicos da cidade, projetando uma cidade acessível a todos.

Em termos de Brasil, uma referência que devemos ter como guia para avaliação da qualidade urbana em função da oferta de espaços livres é a da "Carta a Londrina e Ibiporã" (SBAU, 1996), na qual, após conferências entre pesquisadores e especialistas, é divulgado o padrão mínimo de $15 \mathrm{~m}^{2} / \mathrm{hab}$. de espaços livres dedicados ao lazer. Observa-se aqui o termo "lazer", que revela o cuidado da SBAU em diferenciar os vários tipos e funções dos espaços livres, excluindo desse índice aqueles espaços qualificados como verde viário, cemitérios, hortas ou unidades de conservação. (FONTES, CARVALHO, 2008) 
Partindo da afirmação acima, e com o olhar voltado para o projeto urbano de HafenCity, surgem duas questões: ainda é válido julgar uma cidade ou um ambiente urbano por alguma quantificação de espaços verdes e públicos? A acessibilidade pode ser medida por cartilhas e normas que proporcionam desenhos de rampas e soluções arquitetônicas ruins, destinadas apenas a cumprir normas?

Segundo Brocaneli (2007, p. 208):

Através da incorporação dos conceitos ambientalistas no âmbito das operações urbanas, tendo como foco a regeneração do meio ambiente na cidade, haveria a formulação de cenários interessantes à iniciativa privada e ao poder público devido à valorização do território e da cidade, de forma que as operações urbanas autônomas, rompendo os padrões urbanísticos estabelecidos, formulariam demonstrações das diferentes formas de reestruturação ambiental nas quais a cidade adquiriria qualidade de vida e qualidade ambiental, além de promover outras fontes de renda associadas ao lazer e ao turismo.

Apesar de HafenCity não considerar a bacia hidrográfica como a menor unidade de gestão ambiental, como definido por Odum (1988), ainda assim, apresenta preocupações com o fluxo das águas, ao considerar a dinâmica das inundações, que a área de HafenCity deve absorver e sopesar, mesmo que sem um trabalho de "borda" relevante e condizente com a "teoria dos ecossistemas" de Dramstad, Olsom e Formam (1996).

A delicadeza dos espaços públicos em HafenCity não contemplou o desenho ecossistêmico, no que tange à reprodução e à preservação de nichos para a fauna local, mas o projeto assume um macrodesenho de características ecossistêmicas interessantes, quando contempla a questão das cheias recorrentes.

A cidade de Hamburgo difere drasticamente da cidade de São Paulo, porém apresenta exemplos interessantes e inspiradores para o desenho e a reestruturação desta cidade, no conjunto das áreas das operações urbanas, sendo, HafenCity, inspiração para o desenvolvimento de uma rede de espaços urbanos verdes e públicos, em cotas secas ou inundáveis, a fim de reestruturar a qualidade de vida do paulistano de forma mais acessível. 


\section{RESULTADOS}

HafenCity surge no início do século XXI, como "extensão" de um pensamento ecossistêmico que respeita as características ambientais do espaço urbano, em antiga área portuária e com cheias recorrentes, desenvolvendo com primazia uma rede de espaços públicos acessíveis, inundáveis, secos e semi-inundáveis, como instrumento de reestruturação urbana.

No cenário internacional, HafenCity apresenta possibilidades para a reestruturação urbana em áreas de inundação recorrente, considerando-as como espaços de boa qualidade e democráticos, acessíveis a todos.

HafenCity é um exemplo, internacional e contemporâneo, de que a mobilidade depende do contexto a que se aplica e, quando aliada à acessibilidade arquitetônica, deve refletir prioridades e particularidades locais e regionais.

O conjunto das áreas das operações urbanas em São Paulo apresenta uma série de pontos de inundação, e um desenho urbano que favorece o distanciamento da água, inibindo sua observação, devido à inexistência de espaços a ela dedicados. HafenCity é uma inspiração para o redesenho das margens dos rios paulistanos, principalmente em áreas de operações urbanas, nas quais os instrumentos urbanísticos poderiam auxiliar na recuperação da cidade, com a restituição de áreas públicas verdes e úmidas, que colaborassem para a melhoria da qualidade de vida e da qualidade ambiental em São Paulo.

\section{REFERÊNCIAS BIBLIOGRÁFICAS}

AVRITZER, L. A moralidade da democracia. Belo Horizonte: Editora da UFMG, 1996.

BENEVOLO, L. História da cidade. 2. ed. São Paulo: Perspectiva, 1993.

BROCANELI, P. F. O ressurgimento da água na paisagem paulistana: fator fundamental para a cidade sustentável. Tese (Doutorado em Arquitetura e Urbanismo) - Faculdade de Arquitetura e Urbanismo, Universidade São Paulo, São Paulo, 2007. 
Matrizes Naturais e Matrizes Urbanas: limites e bordas na paisagem da cidade de São Paulo. $4^{\circ}$ Forum de Pesquisa FAU-Mackenzie, 20 a 24 outubro 2008. Mackenzie, SP.

CULLEN, G. Paisagem urbana: tratado de estética urbanística. Barcelona: Blume, 1981.

DAMATTA, R. A casa \& a rua: espaço, cidadania, mulher e morte no Brasil. 5. ed. Rio de Janeiro: Rocco, 1997.

DI FIDIO, M. Architettura del paesaggio. 3. ed. Milano: Pirola Editores, 1990.

DRAMSTAD, W. E.; OLSON, J. D. e FORMAN, R. T. T. Landscape Ecology Principles in Landscape Architecture and Land-Use Planning. Washington, DC: Harvard University Graduate School of design, Island Press and American Society of Landscape Architects, 1996.

FONTES, N; CARVALHO, P. F. "Análise de demanda em um sistema de espaços livres urbanos". In: Congresso Luso Brasileiro para o Planejamento Urbano, 3, 2008, Santos. Santos: PLURIS, 2008. CD-ROOM.

HERTZBERGER, H. Lições de Arquitetura. São Paulo: Editora Martins Fontes, 1999.

LEFÈBVRE, H. O direito à cidade. São Paulo: Centauro, 2001.

LLARDENT, L. R. A. Zonas verdes y espaços libres en la ciudad. Madrid: Closas. Orcoyen, 1982.

LOBODA, C. R.; DE ANGELIS, B. L. D. Áreas verdes públicas urbanas: conceitos, usos e funções. Ambiência - Revista do Centro de Ciências Agrárias e Ambientais. v. 1, n. 1 jan/jun. 2005

MATOS, F. L. Espaços públicos e qualidade de vida nas cidades - O caso da cidade Porto. Observatorium - Revista Eletrônica de Geografia, v. 2, n. 4, p. 17-33, jul. 2010.

MILANO, M. S. Avaliação quali-quantitativa e manejo da arborização urbana: o caso de Maringá. PR. 1988. 120 p. Tese (Doutorado em Engenharia Florestal). Setor 
de Ciências Agrárias, Universidade Federal do Paraná, Curitiba, 1988.

ROSA, I. S. P. Factores determinantes para o planeamento urbano sustentável de zonas com risco de cheia. Dissertação apresentada na Faculdade de Ciências e Tecnologia da Universidade Nova de Lisboa para obtenção do grau de Mestre em Engenharia Civil - Perfil de Construção. Orientador: Professor Doutor Miguel Pires Amado, Junho de 2011.

SALGUEIRO, T. B. Cidade Posmoderna. Espaço Fragmentado. Inforgeo, Lisboa, Associação Portuguesa de Geógrafos, n. 12/13, dez. 1998, p. 225-236.

SANTOS, M. Espaço e método. São Paulo: Studio Nobel, 1985.

VIEIRA, Liszt. Cidadania e globalização. Rio de Janeiro: Record, 1997.

\section{Sites Consultados}

<http://www.contemporaneu.com.br/p/revista.html>, acesso em 10/09/2012.

<https://maps.google.com.br/maps?hl=pt-BR\&tab=wl> acesso em 20/07/2012.

<http://www.crpg.pt/temasreferencia/acessibilidades/Paginas/oqueeaacessibilidade. aspx\#t1>acesso em 15/09/2012. 